\title{
The Meguma Group
}

IAN MCK. HARRIS

Atlantic Geoscience Centre, Geological Survey of Canada, Dartmouth, Nova Scotia

PAUL E. SCHENK

Department of Geology, Dalhousie University, Halifax, Nova Scotia

\section{Introduction}

The Lower Paleozoic Meguma Group of southern Nova Scotia is a thick succession of graywackesandstone, siltstone and slate that was deposited in a deep-marine, eugeoclinal setting. The Meguma strata were folded, intruded and regionally metamorphosed during the Devonian Acadian Orogeny (Poole 1967, Poole et a1. 1970). The major folds tend to be tight to open, upright, low-plunging and generally persistent features (e.g., Fig. 1) up to $150 \mathrm{~km}$ in length and $15 \mathrm{~km}$ in width (Fyson 1966). These folds form a distinctly arcuate pattern that is evident in geological maps of the region (see Fig. 3 of Schenk, Regional Synthesis, this volume). A marked regional cleavage parallels the trend of the folds. Northwest-trending faults offset the folds, with horizontal separations (generally left-lateral) of up to $6 \mathrm{~km}$. Small faults with normal or reverse movements are numerous but have relatively little influence on the regional structure. Two sets of minor cross-folds are associated with the general fracture pattern but generally are not conspicuous at the outcrops. The absence of volcanic rocks in the Meguma Group, overturned folds, and low-angle thrust faults is notable.

Intrusions, ranging from granite to quartzdiorite in composition, truncate the folds without changing the fold trends (Poole et al. 1964). K-Ar

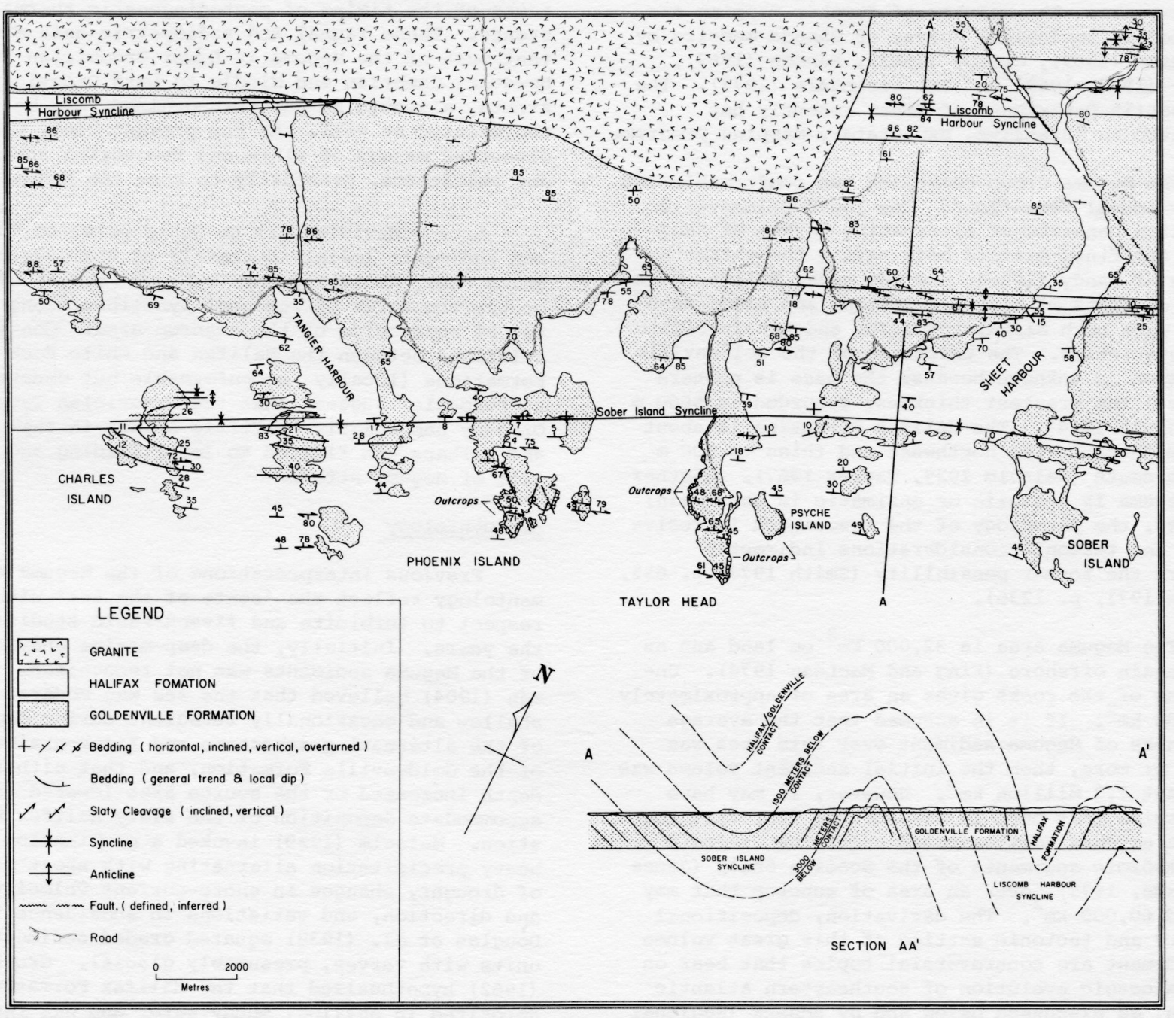

FIG. 1. Geology of the Taylor Head and Phoenix Island area, Nova Scotia (location indicated in Fig. 3 of Schenk, Regional Synthesis, this volume). 
and $\mathrm{Rb}-\mathrm{Sr}$ ages determined for the intrusions range from 318 to $417 \mathrm{my}$, with a peak at $370 \mathrm{my}$ (Fairburn et al. 1960, Fairburn et al. 1964, Lowdon et al. 1963, Leech et al. 1963, Cormier and Smith 1973, Reynolds et al.1973). At Stop 8, where extensive coastal outcrops will be examined, the rocks of the Meguma Group have been affected by chlorite-grade, regional metamorphism; metamorphic grades tend to be higher in other parts of the Meguma outcrop area (Taylor and Schiller 1966).

At the turn of this century, most of the Meguma area was mapped at a scale of one mile to the inch with a view to delineating favourable structures for gold deposits. The gold occurs in quartz veins that tend to follow or cut obliquely across the bedding, and that are particularly well developed at anticlines and domes where they form 'saddle reefs' (Malcolm 1929). Scores of small mines produced gold from these deposits in the early 1900's. Significant production ceased in the mid 1930 's, but rising gold prices have greatly stimulated gold-exploration activities in the area in recent years. The results of further mapping are reported in Geological Survey of Canada memoirs by Stevenson (1959), Crosby (1962), Benson (1967), Taylor (1967, 1969) and Smitheringale (1973). The Nova Scotia Department of Mines recently has initiated an intensive, exploratory mapping program.

The Meguma Group comprises two conformable and partly coeval formations. The lower Goldenville Formation consists of alternating layers of sandstone and finer-grained beds having the characteristics of sandy flysch, and the upper Halifax Formation consists of slate, siltstone and minor sandstone with both distal turbidite and non-turbidite characteristics. The thickness of the Goldenville Formation is unknown because the base is nowhere exposed; the greatest thickness recorded is $5600 \mathrm{~m}$ (Faribault 1914). The Halifax Formation is about $4400 \mathrm{~m}$ thick in the northwest and thins to $500 \mathrm{~m}$ in the south (Malcolm 1929, Taylor 1967). Whether the Meguma is ensialic or ensimatic is uncertain; however, the petrology of the associated intrusive rocks and tectonic considerations indirectly support the former possibility (Smith 1974, p. 655, Schenk 1971, p. 1236).

The Meguma area is $32,000 \mathrm{~km}^{2}$ on land and as much again offshore (King and MacLean 1974). Unfolding of the rocks gives an area of approximately $128,000 \mathrm{~km}^{2}$. If it is assumed that the average thickness of Meguma sediment over this area was $10 \mathrm{~km}$ or more, then the initial sediment volume was at least 1.3 million $\mathrm{km}^{3}$. However, it may have been twice that much in view of the fact that the Meguma extends southeastward under the Cenozoic and Mesozoic sediments of the Scotian Shelf (Jansa and Wade, 1975), over an area of subcrop that may exceed $60,000 \mathrm{~km}^{2}$. The derivation, depositional history and tectonic setting of this great volume of sediment are controversial topics that bear on the Paleozoic evolution of southeastern Atlantic Canada, as discussed below and by Schenk (Regional Synthesis, this volume).

Fossils occur sparingly in the Meguma Group, and as a consequence the stratigraphy has not been worked out in detail. Near Wolfville (the starting point of the field trip), occurrences of the graptolite Dictyonema flabelliforme (Eichwald) in Halifax slate at the 2000-m horizon, approximately, below the contact with the conformably overlying White Rock Formation indicate a Tremadocian age for the Halifax strata (Crosby 1962). Poorly preserved graptolites (probably Didymograptus) of possible Arenigian age have been reported from a road-cut in the Goldenville Formation near the head of Tangier Harbour (Fig. 1) (Schenk 1970, Poole 1971). K-Ar ages of $476 \pm 19$ my and $496 \pm 20 \mathrm{my}$ for detrital muscovite from samples of Goldenville sandstone at Stop 8 (Taylor Head and Pheonix Island, Fig. 1) contrast with the younger ages obtained for more highly metamorphosed rocks and granitic intrusions at other localities in the Meguma outcrop area (Poole 1971, Wanless et al. 1972). The detrital muscovite determinations conform with the fossil evidence cited above, hence, they possibly represent the approximate time of deposition or diagenesis of the sediment, rather than the age of the source rocks or the timing of post-diagenetic thermal events。 These faunal and radiometric data suggest that much of the Meguma is Lower Ordovician in age. However, Cambrian and Middle to Late Ordovician strata, although as yet unrecognized, may be represented as well. At the present time, we are digesting masses of slate and recovering acritarchs and chitinozoa, eventually to zone the Meguma.

Late Ordovician (?) to Early Devonian volcanics and sediments (mainly detrital) of the overlying White Rock, Kentville and Torbrook Formations occupy the cores of regional synclines along the Bay of Fundy side of the outcrop area. Contact relations between the Halifax and White Rock Formations (locally unconformabie but generally conformable) suggest that the Ordovician Taconian Orogeny had relatively little effect in this area, and perhaps was limited to local folding and uplift of Meguma strata.

\section{Sedimentology}

Previous interpretations of the Meguma sedimentology reflect the 'state of the art' with respect to turbidite and flysch-basin studies over the years. Initially, the deep-marine character of the Meguma sediments was not recognized. Woodman (1904) believed that the sea was moderately shallow and occasionally turbulent during deposition of the alternating sandstone and finer-grained beds of the Goldenville Formation, and that either water depth increased or the source area lowered to accommodate deposition of the slaty Halifax Formation. Malcolm (1929) invoked a combination of heavy precipitation alternating with short periods of drought, changes in shore-current velocity and direction, and variations in subsidence rates. Douglas et al. (1938) equated graded sedimentation units with varves, presumably glacial. Crosby (1962) hypothesized that the Halifax Formation was deposited in shallow, muddy water and was influenced by seasonal fluctuations of unspecified nature. Phinney (1961) examined several outcrops of the Goldenville Formation northeast of Halifax and was 
the first to conclude that the Meguma is a turbidite succession. Taylor (1967) suggested that northwestward-moving turbidity currents filled an initially deep-marine basin, so that the sea became shallow and muddy. Campbell (1966) made a preliminary survey of the Goldenville sedimentology in a $6000-\mathrm{km}^{2}$ coastal area, and concluded that turbidity currents flowing from the southeast deposited the sediments in a northeastward-plunging, deepsea trough.

Schenk (1970 and unpublished data) undertook a sedimentologic study of the entire Meguma area, and on this basis outlined the following characteristics of the sediments: (1) The Goldenville Formation comprises sandy flysch; the Halifax Formation is composed of several facies of dominantly fine-grained sediments, of which shaly flysch is probably predominant. The shaly flysch is distinguished from other facies of the Halifax Formation by the preponderance of beds displaying the Bouma sequence of structures, mainly CDE and BCDE. (2) Graded bedding is generally weakly developed in the thick sandstone beds that make up much of the Goldenville Formation. However, a few of the thick beds display excellent, continuous grading. Normally, grading is restricted to the upper few centimetres of sandstone beds; the main part of the bed typically has a uniform distribution of grain sizes, and generally either is structureless or has diffuse parallel lamination. This lamination is distinct from the sharply-defined, planar lamination that occurs towards the tops of many beds ( $i$ 。e., the Bouma $B$ division). The Bouma $C$, ripple-laminated division is widely developed in parts of the Halifax Formation and in relatively thin beds of the Goldenville Formation, but is generally restricted in development or missing altogether in the upper portions of thick sandstone beds. (3) Lenses and layers of conglomeratic material occur in some beds mainly composed of sandstone, particularly in the lower parts of the beds. Beds made up entirely of conglomerate or conglomeratic sandstone are rare。(4) Intraformational clasts (mudstone-siltstone rip-ups) are components of many of the Goldenville beds. They occur preferentially in thick beds, and probably were derived from the undercutting of channel walls. (5) Groove markings are abundant on the undersurfaces of beds in the Goldenville Formation, but are relatively uncommon in the Halifax Formation. (6) Flutes are especially abundant in the transitional zone between Goldenville and Halifax lithosomes (where the sand/shale ratio is close to unity), and are common but less abundant than grooves in the Goldenville sandy flysch. (7) Channels that eroded up to three metres into the pre-existing layers are evident at many outcrops. Larger channels, although present, are generally too large for their whole shape to be viewed in outcrop. (8) Load structures are very abundant in the Goldenville Formation. Many are associated with asymmetrical flame structures formed by sand foundering into fine-grained material during the deposition of the bed. Load-balis (pseudonodules) are locally well developed in the shaly flysch of the Halifax Formation (Stop 6). (9) Trace fossils are present at many outcrops, but generally not in great numberso Vertical shafts, some twinned (presumably
U-tubes), are the most visible biogenic structures in the Halifax Formation, and the trails of organisms are conspicuous at the base of some sandstone beds in the Goldenville Formation. Several Nereites-type forms have been recovered from the Goldenville. Sand volcanoes at upper bedding surfaces and vertical pillar structures within sandstone beds probably represent both organic and inorganic dewatering structures.

Schenk used a $3 \times 4-\mathrm{km}$ grid as a guide for selecting outcrops throughout the Meguma area, at which he collected sedimentologic data. These data provided the basis for an evaluation of the regional variations of directional, textural, and compositional properties, illustrated by trendsurface and moving-average maps. Analyses of directional measurements of current structures at each outcrop indicate that the paleocurrent trend is axial, and turns 90 degrees from due north in the southwest to due east in the eastern part of the area. Local variations to this trend are consistently toward the northwest. This paleocurrent pattern persists through all horizons of the Meguma. The paleocurrent trend appears to "contour" the scalar properties - i.e.. currents trend along, not across contours of such properties as grain size, layer thickness, percent lithic clasts, etc. Stated another way, the paleocurrent trend is almost at right angles to the dispersal direction inferred from the lateral variations in sandstone grain-size and composition, maximum and average bed thickness, and other sedimentologic properties. To explain these characteristics of Meguma sedimentation, Schenk proposed that the sediments were moved into the area mainly by turbidity currents, slump and creep, but were reworked by contour-following bottom currents that flowed northwards in the southwestern part of the area and hooked right to flow eastward in the northeast. According to this view, directional structures indicate the direction of the last current, whereas other structures and the texture and composition give the initial downslope path. Schenk compared the depositional environment with that of the present continental rise of the western North Atlantic, where contour-flowing bottom currents are an important agent of sediment transport and deposition (Heezen et al. 1966). This model agreed with the interpretations of workers who invoked normal ocean currents, rather than turbidity currents and related processes, to explain flysch sedimentation in other areas where the relationship between paleocurrents and the apparent paleoslope is seemingly anomalous (e.g., Hubert 1966, 1968, Klein 1966, Scott 1966). Later work by Harris (1971, 1975) and Schenk (1973) and reinterpretation of the comparable situations in other flysch basins (e.g., walker 1970) suggest that this model does not satisfactorily explain the Goldenville sandy flysch, but nevertheless is valid for the non-turbidite part of the Halifax Formation.

Harris (1971) carried out a bed-by-bed study of sedimentary structures in the Goldenville Formation at coastal exposures in the area outlined in Fig. 1. This work brought to light the following characteristics of the Goldenville sediments in that area: (1) Sandstone (dominantly fine- to medium-grained) constitutes at least 70 


\section{LEGEND}

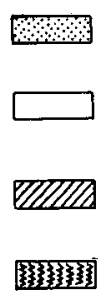

Sandstone (average grain-size $>0.1 \mathrm{~mm}$. )

Very fine sandstone, siltstone and mudstone transitional above a sandstone bed

Interbedded very fine sandstone, siltstone and mudstone

Maximum Grain Size (Field Estimate)

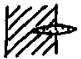

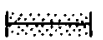

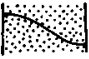

and

1.

$\equiv \approx$

WN $N E$ with contorted laminae of sandstone and siltstone
Slump-deformed zones of silty mudstone coarse $\left(\frac{1}{2}\right.$ to $\left.1 \mathrm{~mm}.\right)$

$\gamma \tau N E$

Sharp contact between sandstone above and finer-grained sediments below

Transitional contact between sandstone below and fine-grained sediments above

Amalgamated bedding

Channelled, amalgamated bedding

Discontinuous, erosionally truncated sandstone bed, in sharp contact with fine-grained rocks above and below

Flat intra-bed surface in compound sandstone bed

Channelled intra-bed surface in compound sands tone bed

Discontinuous layer in compound sand stone bed, marked by joined intrabed surfaces

Intra-bed surface marked by abrupt change in grain-size

Paralle1 lamination in sandstone (even, wavy)

Cross-lamination in sandstone (associated with internal flutes, associated with channels - inferred current direction toward the northeast)

CH

FL

LF

$P D$

$\sim \sim N E$
vor $v$

שU
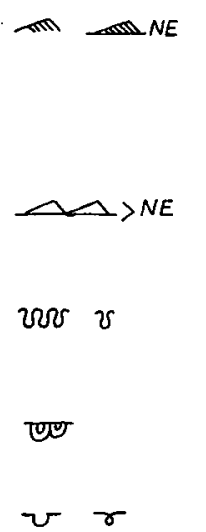

Ripple cross-lamination (in very fine sandstone and siltstone interbedded with mudstone, in sediment at the top of and transitionally above sandstone beds inferred current direction toward the northeast)

Ripple-mark on upper bedding-surface of sandstone bed, inferred current direction toward the northeast

Intra-bed slump folds and associated primary deformation structures (strongly developed, weakly developed)

Erosiona11y truncated, intra-bed slump folds in compound sandstone beds

Load structures (at under-surface of sandstone beds, semi-detached pseudonodules of sandstone and sandy siltstone depressed into silty mudstone and mudstone)

Flame structures (symmetrical and random1y assymetrica1, preferentially assymetrical - leaning towards the northeast)

$2 \& L G$

Mudflake inclusions (maximum observed length $\leqslant 1$ meter, maximum observed length $>1$ meter)

Channels

GV45 GV45)

Grooves (tilt-corrected orientation is $45^{\circ}$ azimuth, orientation is $45^{\circ}$ azimuth inferred northeastward current direction, two sets of grooves - at $70^{\circ}$ and $120^{\circ}$ azimuth)

Flutes, azimuths and current directions indicated as in the case of grooves

Longitudinal furrows, azimuths and current directions indicated as in the case of grooves

$G V+F L+L F(35) \quad$ Grooves, flutes and longitudinal furrows inferred southeastward current direction

SL90 S1ide markings, ti1t-corrected orientation is $90^{\circ}$ azimuth

Prod markings

IIII Sand pipes

TाT Sheet structures

(2) Sand mounds

Biogenic structures on sole of bed

Sole of bed not exposed

FIG. 2. Graphic log and sedimentary structures of representative strata of the Goldenville Formation, Phoenix Island. Structures called 'sand pipes' and 'sand mounds' in the legend are referred to as 'pillar structures' and 'sand volcanoies' in the text. 


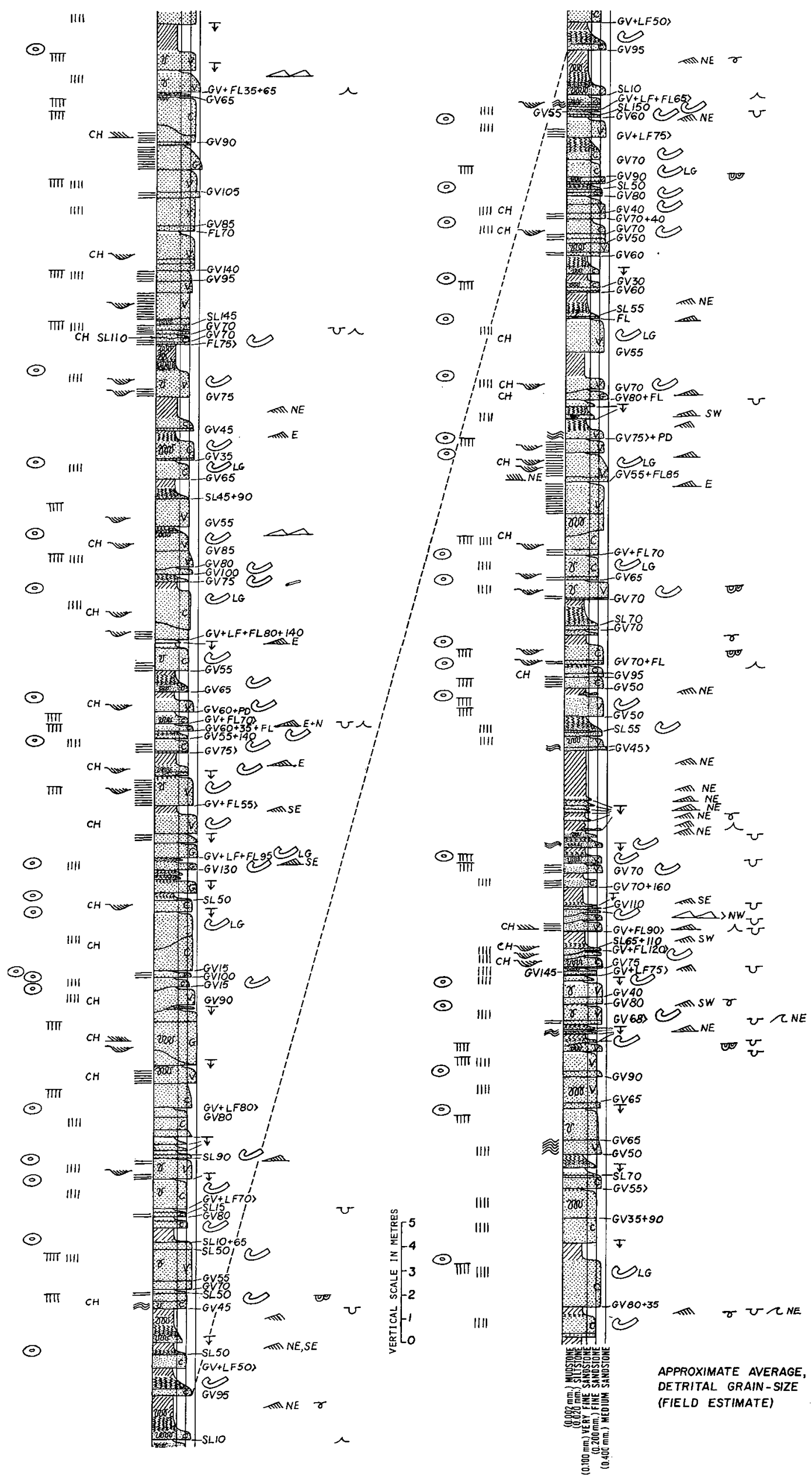


percent of the formation and occurs in beds $1 \mathrm{~cm}$ to more than $50 \mathrm{~m}$ thick. To explain the predominance of fine-grained sandstone, Harris suggested that the Goldenville sediments were transported by turbidity currents down submarine channels, and that portions of both the coarse and fine fractions were left behind in 'upstream' areas. According to this view, some of the argillaceous material accumulated in interchannel areas and on a prograding continental rise, ultimately to form a part of the Halifax Formation. (2) The sandstone beds, when traced along strike from outcrop to outcrop over a distance of several kilometres, commonly appear either to be discontinuous or to become segregated into a number of thinner beds or to become amalgamated into thicker beds. In vertical sequence, the sandstone beds form thickening-upward, large-scale megarhythms (the vertical extent of each megarhythm is from 200 to $700 \mathrm{~m}$ ). Harris suggested that these characteristics of the beds indicate deposition in a prograding submarine fan system. Both thickening-upward and thinning-upward megarhythms are present on a smaller scale as well. The average small-scale megarhythm has a vertical extent of approximately $25 \mathrm{~m}$. Flysch studies in other areas in recent years have convincingly demonstrated that such megarhythms may be attributed to channel-fill (thinning-upward) and unchannelled (thickening-upward) deposition in the 'suprafan' areas of submarine fan complexes (see reviews by Walker and Mutti 1973, Mutti 1974). (3) Analyses of numerous measurements of directional sole markings, coupled with good structural control, indicated that the mean paleocurrent direction is closely parallel to the trend of the major folds, substantiating Schenk's finding that the regional paleocurrent trend is axial. A possible explanation is that the currents flowed parallel with the long axis of a tectonically-controlled trough, and that later the folds developed axial to the trough. Harris favoured another interpretation, however. He surmised that the paleocurrents determined the geometry or 'grain' of the sandstone beds, which, in turn, controlled the early development of the main folds. He suggested that the early folds were later steepened and rotated into a stable tectonic position. However, the amount of horizontal rotation that may have been involved is unknown. (4) Many of the sandstone beds have deeplytooled groove markings on their undersurfaces, commonly associated with scour depressions that in numerous instances are deformed by loading. Intrabed scour-and-fill structures are prominent in some beds, and outsize intraformational clasts (>Im in length) are present in others. These features suggest the action of high-energy currents. (5) Dewatering structures, such as sand volcanoes, pillar structures and sheet structures (see descriptions, Stop 8), are present in about half of the sandstone beds. These features indicate that the sand was highly water-laden, apparently as a result of rapid deposition from currents highly charged with suspended sediment. Abundant slump structures and slide markings further attest to the unstable and presumably water-laden conditions of the sediments. (6) The mean direction of slide markings is parallel to the mean paleo-current direction, suggesting that both the currents and slides moved down-slope. However, the slope may have been controlled by the configuration and siting of the main depositional lobes of the submarine fan complex rather than by the regional bathymetry.

Descriptions in recent years of both modern deep-sea fans and inferred ancient deep-sea fans (see reviews by Walker 1970, 1973, Walker and Mutti 1973, Mutti 1974, Nelson and Kulm 1973, and Nelson and Nilsen 1974) have contributed greatly to an improved understanding of flysch (and hence Meguma) sedimentology. The application to the Goldenville Formation of recent work on megarhythms was noted above. Schenk (1973) drew attention to the striking similarity of the Goldenville and Halifax lithologies to present, abyssal plain turbidites and continental rise contourites of the western North Atlantic, as described by Horn et al. (1971). This comparison supports the concept that the Meguma sediments accumulated in a deep-marine setting. In the region of the Hatteras Abyssal Plain (the area of abyssal sand and silt accumulation in Fig. 5 of Schenk, Regional Synthesis, this volume), channelized turbidites are being deposited by turbidity currents that move in the same general direction as the contour-following currents that transport and deposit the fine-grained sediments of the adjacent continental rise, and both flow approximately parallel with the continental margin. The continental rise sediments presumably are prograding outwards over the Hatteras Abyssal Plain, transverse to the direction of the depositional currents. The sedimentation and regional paleocurrent pattern of the Goldenville and Halifax Formations may have developed in a similar manner. The paleocurrent directions of the Halifax and Goldenville Formations are mutually parallel, and some of the fine-grained sediments of the Halifax Formation are possible contourites that prograded laterally over the Goldenville sandy flysch. Schenk's (1970) analyses of the Meguma paleocurrents indicate that they probably flowed more or less parallel with the ancient continental margin. A ramification of the theory of plate tectonics is that the principal folds that develop during diatrophism of a eugeoclinal succession juxtaposed with an ancient continental margin may have a tendency to be aligned subparallel with the ancient margin, and in the case of the Meguma, therefore, subparallel with the regional paleocurrent trend.

Middieton and Hampton (1973) described and classified the bed-forms that result from deposition by four possible mechanisms of sediment gravity (mass) flows, namely, (1) turbidity currents, (2) fluidized sediment flows, (3) grain flows and (4) debris flows. The great majority of sandstone beds in the Goldenville Formation have bedding characteristics that indicate deposition by turbidity currents, fluidized sediment flows, and grain flows. However, relatively few of the beds can be categorized as exclusively the product of any one of these three mechanisms. The sequence of sedimentary structures in most beds suggest that more than one of the mechanisms operated simultaneously or successively during the process of deposition. Representative beds of the Goldenville Formation and their characteristic sedimentary structures are depicted in Fig. 2. We speculate that the sediments were moved into the area primarily by turbidity currents, and that fluidized sediment flow and grain flow became important immediately 


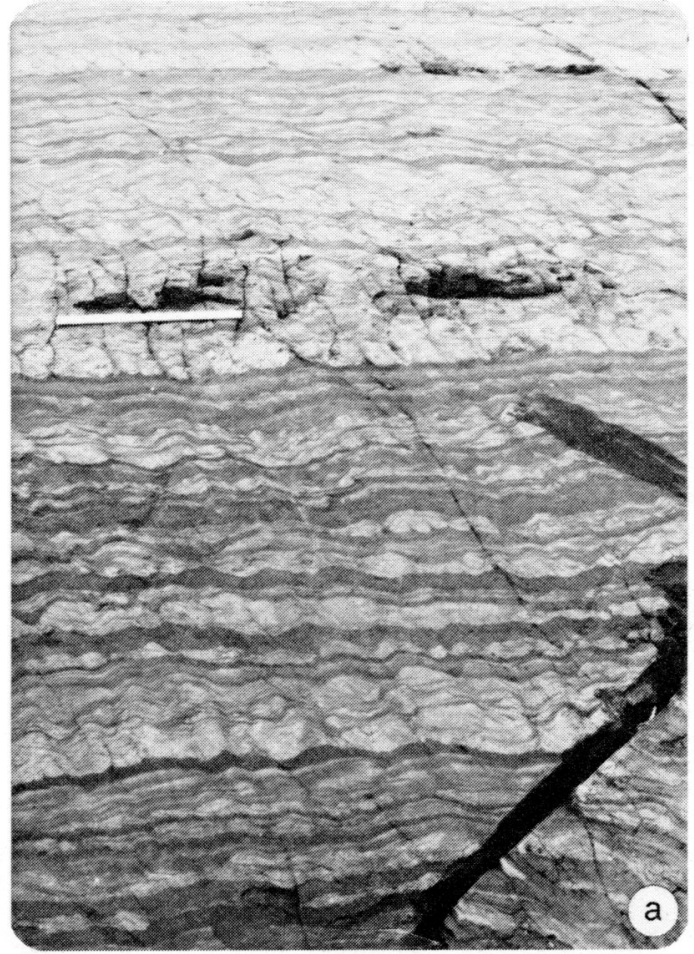

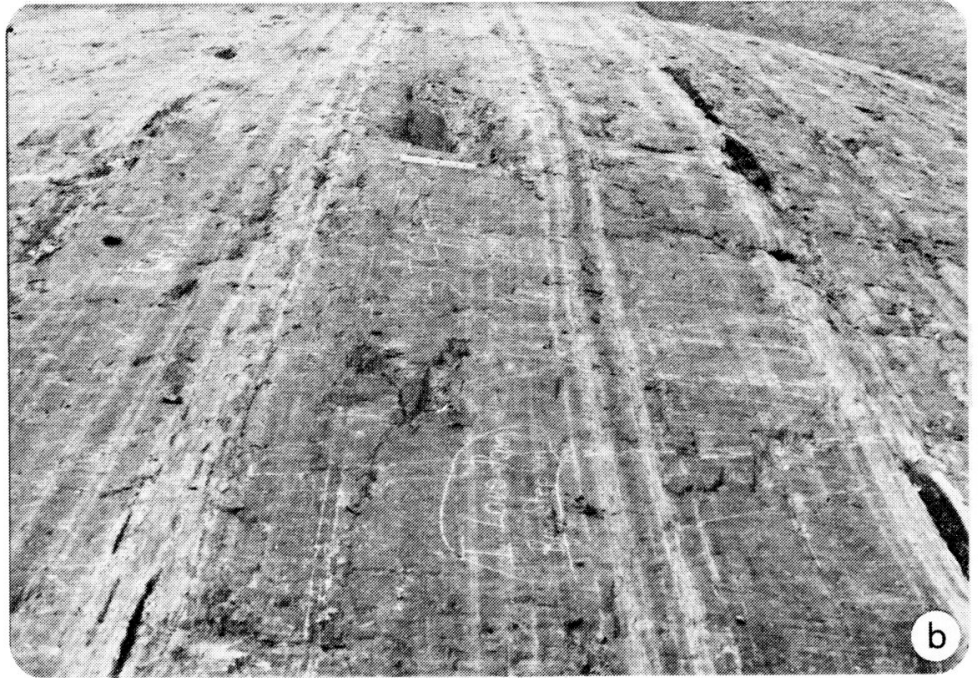

FIG. 3. Two contrasting lithosomes of the Halifax Formation: a. Overbank furbidites (?), Black Point Beach (Stop 6), b. "Distal" turbidites (?), Titus Park (Stop 7). before and during deposition of the majority of the sandy beds. The delayed grading that characterizes many of these beds suggests that turbidity-current action prevailed during the final phase of deposition in such cases. Continuous exposures at Stop 8 will provide field-trip participants with an opportunity to formulate their own opinions as to the nature and origin of the Goldenville sediments.

\section{Facies Associations}

According to the facies classification of Walker and Mutti (1973), the bulk of the Goldenville Formation corresponds to Facies B2 (massive sandstones without dish structure) and Facies $C$ (mainly Boumas $A E$, proximal turbidites), with subordinate Facies A2 (organized conglomerates), A4 (organized pebbly sandstone), and Bl (massive sandstones with dish structures). Occurrences of Facies Al (disorganized conglomerates) and A3 (disorganized pebbly sandstones) are rare. Facies D ("classical" distal turbidites of Walker 1967) and minor Facies $G$ (pelagic and hemipelagic muds and silts) are present as intercalations from tens of centimetres to hundreds of metres thick within the Goldenville Formation. Walker and Mutti equate this association of facies with mid-fan deposition in submarine fan systems.

The Halifax Formation is composed of Facies $D$ and $G$, with minor Facies $C$. A number of environments of deposition are probably represented (e.g. Figs. 3-6)-the outer fan and basin plain; the interchannel areas of the inner fan; and the areas between major channels and canyons on the rise and slope. Upper Halifax strata that grade vertically into neritic deposits of the White Rock Formation probably represent outer shelf deposits that accumulated in relatively shallow water (see Lane, White Rock Formation, this volume). Questionable overbank turbidites (Bouma $\mathrm{CDE}$ and BCDE) in the lower(?) Halifax can be viewed at Stop 6 . Current structures in these sediments indicate a wide range of paleocurrent directions. Halifax slate with thin interbeds of finely laminated siltstone and silty slate (Facies $D$, and $G$ ) at stop 7 possibly represent basin-plain deposits. Similar rocks occupy a large area of westernmost Nova Scotia, north of Yarmouth, immediately west of the main fan system which veers to the east in that vicinity. These sediments apparently were deposited in the quiet lee of a major dispersal point of coeval sandy flysch of the Goldenville Formation. That is, this "distal" facies is actually very proximal.

In the light of these considerations, the conventional view of the Meguma Group as composed of two time-stratigraphic formations identified solely on the basis of Iithology (i.e., the sandy Goldenville and the slaty Halifax) is clearly inappropriate. According to our sedimentologic model, the Meguma is a complex of inter-fingering lithosomes. For example, zones of fine-grained sediments up to $1 \mathrm{~km}$ thick within the Goldenville are interpreted as facies-equivalent to Halifax sediments with comparable sedimentologic characteristics. In broad aspect, the Goldenville and Halifax sediments are at least partly and may be 
wholly coeval. However, our knowledge of facies relationships in the Meguma is far from complete at the present time.

\section{Source Area}

The principal source area of the Meguma sediments lay to the southeast, in the direction of the present continental margin. Sandstone compositions suggest a cratonic, quartz-rich provenance (Schenk 1970, Harris 1971). Extraformational lithic clasts are of gneiss, granite and metasediments, indicating a deeply eroded terrain. Sand-size clasts are mature both in texture and composition, suggesting winnowing and sorting on a continental shelf and alluvial plain. The great volume of Meguma sediments, as well as evidence of a number of local dispersal points along the Atlantic shore, further attest to a southeastern source area of apparently continental dimensions. Schenk (1971, 1972a, 1973) suggested that this continental source area has been removed by continental drift and is presently represented in northwestern Africa (the Saharan Precambrian Shield). This hypothesis is supported by the presence of exotic clasts with faceted and grooved surfaces (presumably dropped from melting icebergs) in the basal White Rock Formation. These glacially derived 'drop-stones' may have been a product of the Upper ordovician glaciation that affected much of Africa and South America (Schenk 1972b).

Schenk (1971) contrasted and compared the stratigraphic and tectonic development of southeastern Atlantic Canada with that of northwestern Africa to search for not only the source of the
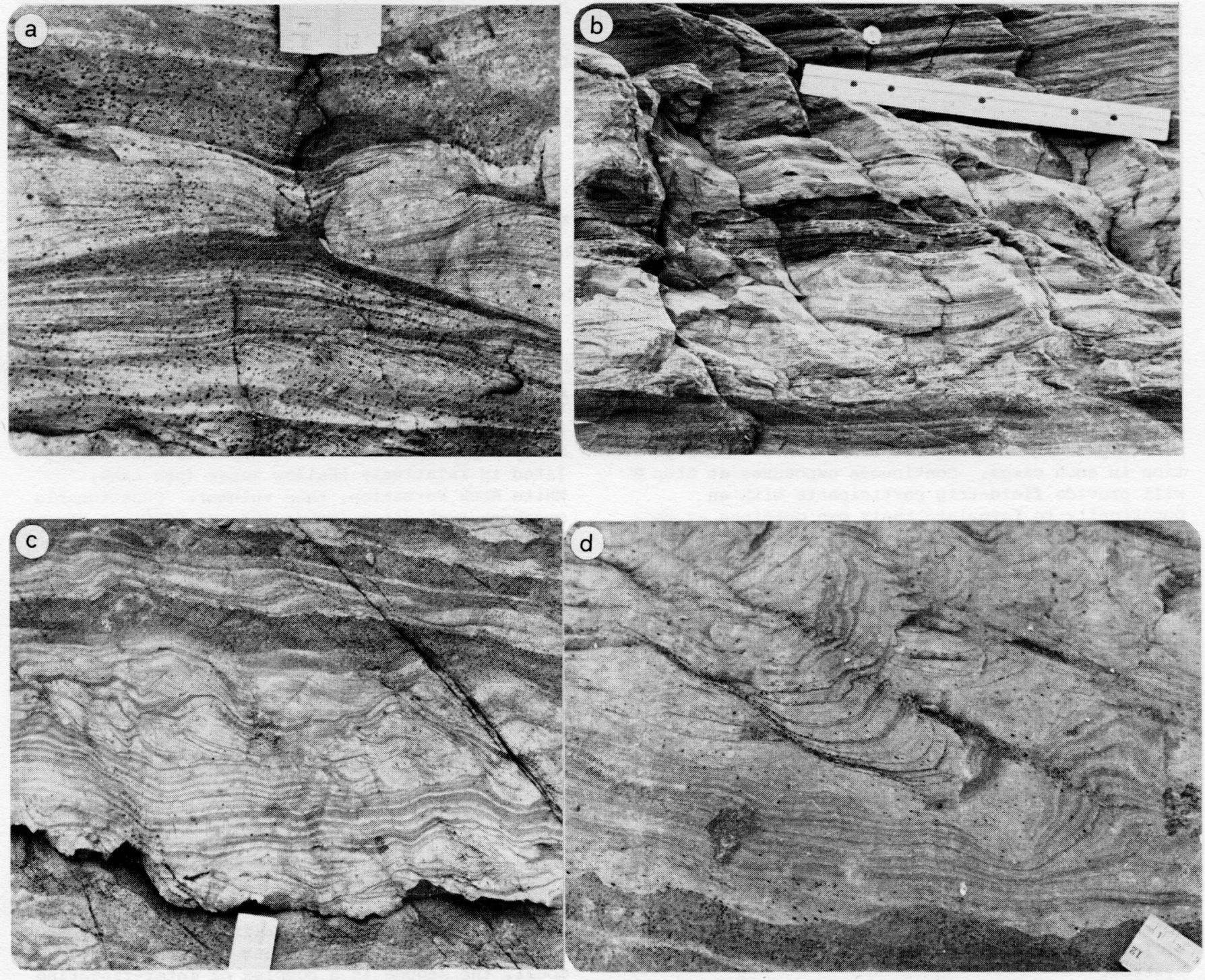

FiG. 4. Sedimentary structures in the Halifax Formation, Black Point Beach (Stop 6), including (a) mud diapirs, (b) irregular carbonate concretion, (c) slump-deformed laminae, and (d) basal laminite cut by cresentic ripples - paleocurrent paralled to ruler. 


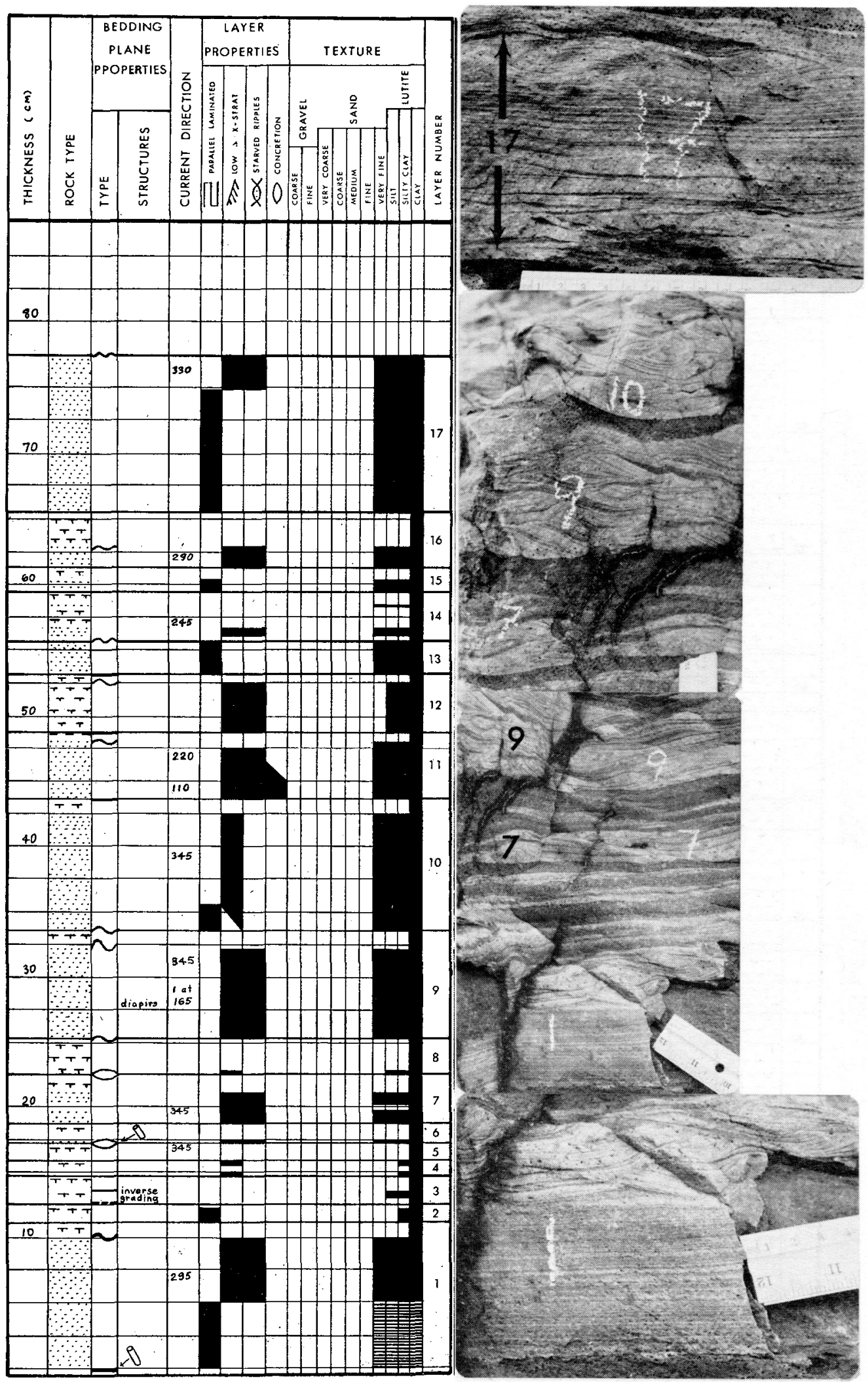

FIG. 5. Sedimentary characteristics of the Halifax Formation at Black Point Beach (Stop 6). 


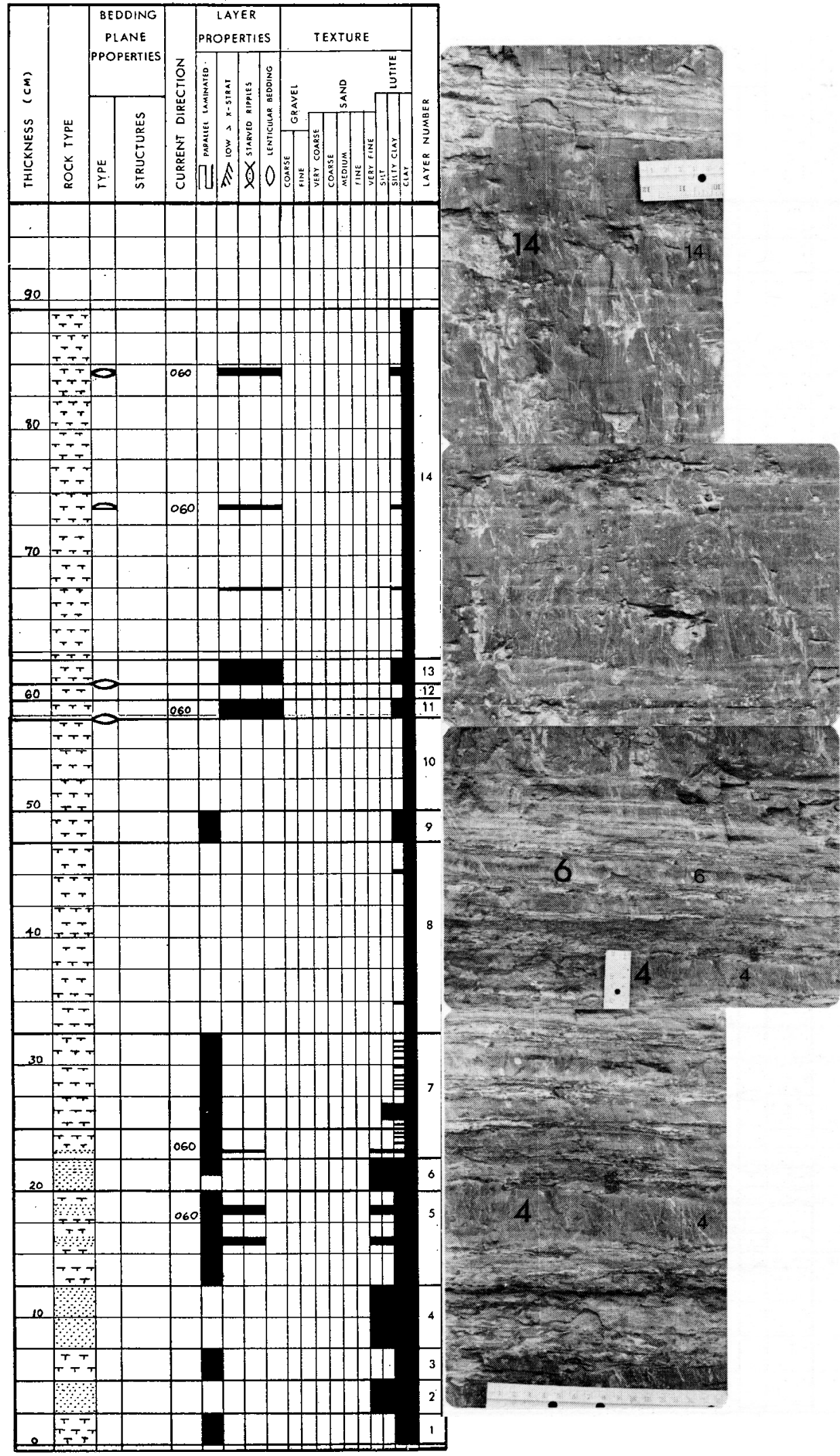

FIG. 6. Sedimentary characteristics of the Halifax Formation at Titus Park (Stop 7). 
Meguma but also the rest of the Meguma's eugeocline. He contended that the Saharan Shield was the source, that the Meguma was broken from the Mauritanide eugeocline of northwestern Africa, and that the Meguma was left behind against North America during post-Paleozoic continental rifting. In northwestern Morocco (the Meseta), thick Paleozoic geosynclinal sediments are flyschoid, turbidite, and volcanogenic. They were intruded by calc-alkaline and alkaline plutons whose $\mathrm{K}_{\mathrm{O}} \mathrm{O}$ increases inland characteristic of granites developed above a subduction zone (Hurley et al. 1974). The ages of these plutons range from 650 to $250 \mathrm{my}$, the younger ones overprinting the older to give a false, only Hercynean age. Hurley et al. believed that the Meseta was an active marginal trench throughout the Paleozoic, and that this trench was due to downplunging oceanic lithosphere dipping beneath the edge of the continent. This subduction ceased in Hercynean time by closing of the Paleozoic Atlantic and continental collision. Meanwhile, southwestern Morocco (the Anti-Atlas) was a stable block. There, Early Cambrian carbonates were covered by siliclastic sands issuing from the Precambrian Saharian Shield (Reguibat massif) to the southeast. Dispersal. patterns of these sands are variable from Mid Cambrian to Late Ordovician time, but are in general toward the northwest. The Meseta eugeoclinal belt is missing off the Anti-Atlas, but continues to the southwest through the Spanish Sahara and further on. Schenk (1975) suggested that the Meguma massif may be that missing segment of the eugeocline, stranded against North America during ragged rifting of the Mesozoic (see Fig. 2 of Schenk, Regional Synthesis, this volume). He envisioned the closing of the Paleozoic to be a "simple", scissor-like movement, with continental collisions starting early with Scandanavia and northern AmericaGreenland in the Late Silurian, southern Europenorthern Africa with the northern Appalachians in the Early Devonian, and central Africa-central southern Appalachians in the late Carboniferous and early Permian.

On the basis of paleomagnetic evidence and tectonic considerations, McKerron and ziegler (1973) proposed that northwestern South America rather than northwestern Africa collided with North America during the Acadian Orogeny; hence, the Meguma sediments conceivably may have had a South American derivation. These authors considered the Erian Orogeny (Late Silurian-Early Devonian) to record collision of North AmericaGreenland with the Baltic Shield following the closure of the ocean that Harland and Gayer (1972) referred to as Iapetus. The Acadian Orogeny sandwiched the Avalon Platform (a very extensive prong of the Baltic Shield) between North America and northwestern South America (from Peru to Venezuela). This collision closed the southern remainder of Iapetus. In the Late Devonian, South America separated from Atlantic Canada again and rotated counterclockwise. This rifting was southeast of the Meguma, so that the Meguma would be a eugeoclinal wedge originally built off northwestern South America and stranded as a remnant against North America. The hypothesis continues: In the Late Carboniferous, Africa north of the South Atlas fault collided both with North America and
Europe (our Maritime Disturbance; their Hercynian Orogeny). Finally, Africa south of the South Atlas fault slid westward on this fault to collide with the central and southern Appalachians to close the ocean (Dewey and Kidd 1974). Additional evidence is required in order to test the validity of these grand-scaled speculations.

\section{Field Stops}

The first stop (Stop 5, see Figs. 1, 4 and 5 of Harris, this volume) is at a roadside outcrop of the Goldenville Formation that displays some unusual sedimentary features. At Stops 6 and 7 (see Fig. 6 of Harris, this volume), glacially-smoothed outcrop-surfaces reveal some of the bedding characteristics of the Halifax Formation. Stop 8 is either at Phoenix Island or Taylor Head (Fig. 1), as explained below. At these localities, extensive coastal exposures of the Goldenville Formation exhibit a wide variety of sedimentary structures.

Stop 5 (Fig. 7) - Highway 102 (Bicentennial Drive), road-cut: Features to note at this outcrop are the thickness of individual, non-composite sand layers (up to 30 metres); antidune cross-lamination; dewatering pillar structures; sole marks; crescentic ripple marks; loaded, phosphate-pebble conglomerate at or near the base of beds; and carbonate concreations. We interpret this as a channel deposit.

Stop 6. (Fïg. 3a, 4, 5) - Black Point Beach, Point Pleasant Park, close by container-port facilities: You are standing where the last authentic pirate was hung in the Halifax area! you are also standing on rocks of the Halifax Formation. The sand/shale ratio is close to unity here but the sand layers are thin. Notice the degree of traction, the starved, loaded ripples, and parallel lamination. The ripples are mainly cresentic. The glaciated surface of this roche moutonnfe shows these ripples best, as well as the small scale folds (Fig. 3a) associated with slip cleavage. Secondary concretions of carbonate occur in many of the sand layers. Some cross-laminations show apparent concentrations of heavy minerals. Is this Iithosome an overbank turbidite, or is it a contourite, or a combination of the two?

Stop 7 (Fig. 3b, 6) - Titus Park, Fairview: The Halifax Formation at this locality shows a lithosome similar to that in the area of extreme western Nova Scotia. The section is mainly metamorphosed clay with very continuous, even, although very thin silt layers, characterized by parallel lamination. Cross-lamination is rare, normally at a very low angle, and at the base of strata. The environment of deposition was very quiet, and as a consequence it is difficult to find way-up criteria. Note the low-angled cleavage and the occasional small-scale folds. Are the latter penecontemporaneous (and downslope indicators), or are they tectonic?

Stop 8 - Phoenix Island and Taylor Head: Coastal outcrops of the Goldenville Formation will be examined either at Phoenix Island or Taylor Head (Fig. 1), depending upon weather conditions. If the weather is fair and the seas are calm, we will travel by power-boat to Phoenix Island from 


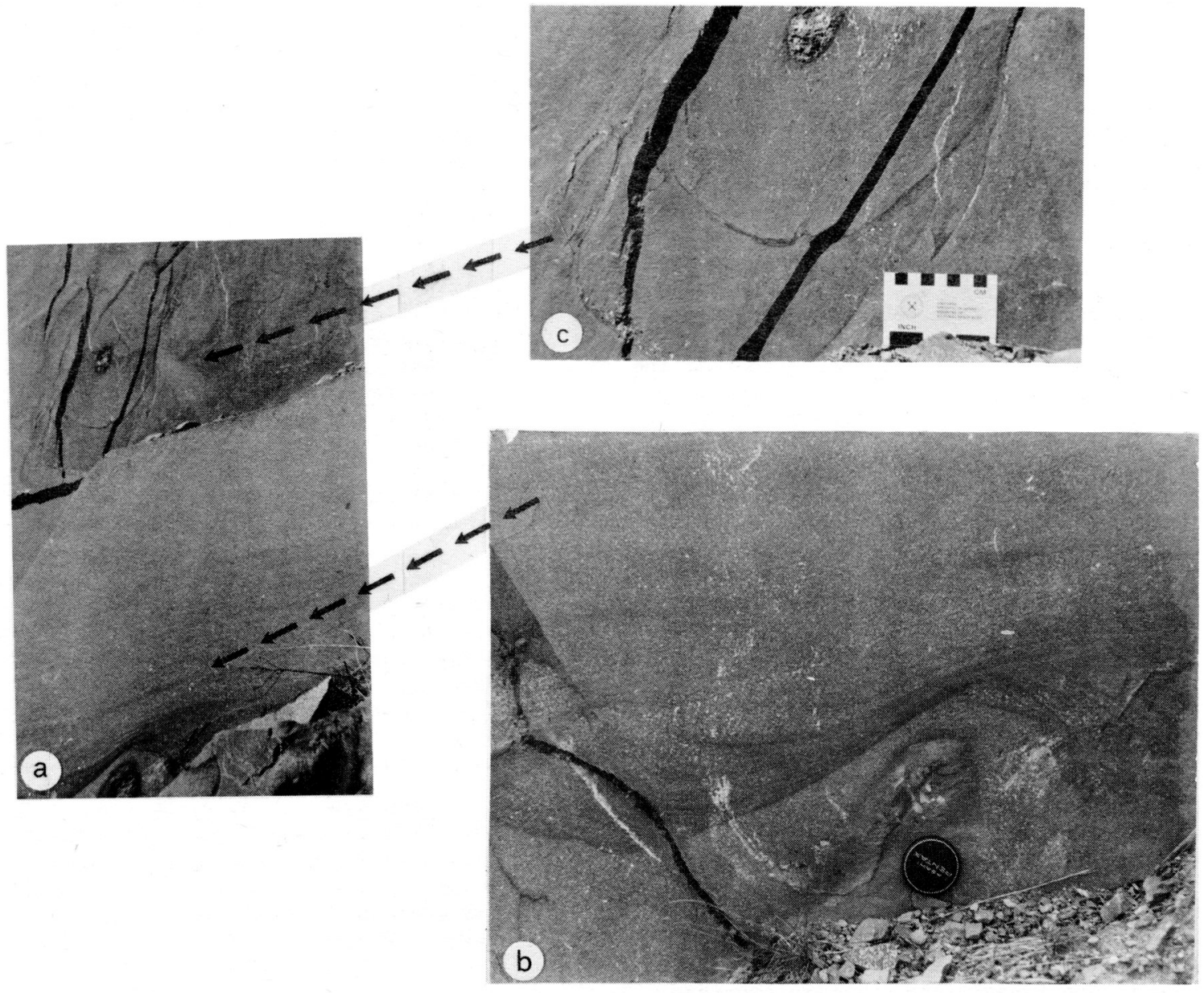

FIG. 7. Sedimentary structures in sandstone of the Goldenville Formation, Bicentennial Highway (Stop 5). a. Cross-lamination(pos. sible antidunes), passing upward into weakly developed, parallel lamination, above which is a structureless zone. Intrabed scour - and load-depressions occur above the parting surface. The two concretionary bodies are iron-stained carbonate. b. Close-up of antidune (?) cross-lamination and lower carbonate concretion. c. Intrabed dewatering structures (note injection 'flame' between loaded scour-depressions, immediately above scale).

a point close by where the highway approaches the shore. If the weather is inclement, we will walk from road's end to good shoreline outcrops at Taylor Head, possibly with a side trip by boat to Psyche Island if sea conditions permit. In either event, we will see fine examples of the sedimentary structures that characterize the Goldenville Formation.

Nearby all of the outer islands and headlands in this area have extensive shoreline exposures. Of these outcrops, Figure 1 indicates those at which the photographs of Figures 8 to 14 were taken. The Phoenix Island, Taylor Head and Psyche Island outcrops all occur on the flank of a major syncline (the Sober Island syncline). This through-going fold is large, nearly upright, and very gentlyplunging, like others in the area. Slaty cleavage is highly developed and tends to obscure sedimentary structures in the finer-grained beds. On the other hand, sedimentary structures in the sandstone beds are superbly displayed.

A graphic $\log$ of a representative portion of the strata exposed on Phoenix Island is presented in Fig. 2. The sedimentary structures depicted in this diagram are much in evidence at all major coastal outcrops in the area. The following remarks refer to some of the salient characteristics of these structures.

Graded bedding. Most of the sandstone beds are tens or hundreds of centimetres thick, and are ungraded except in their upper few centimetres. Some of the beds have relatively sharp upper surfaces, but in most cases delayed grading (grading in the upper few centimetres) is evident. Pockets and lenses of conglomeratic material occur in scourand-fill depressions in the basal part of a few non-composite beds and at various levels in some amalgamated beds. The conglomeratic material grades upward over a few centimetres or tens of centimetres into the sandstone that makes up the main part of the beds. Continuous grading is prevalent in sandy siltstone and siltstone beds that generally occur interlayered with slate in zones between sandstone beds. 

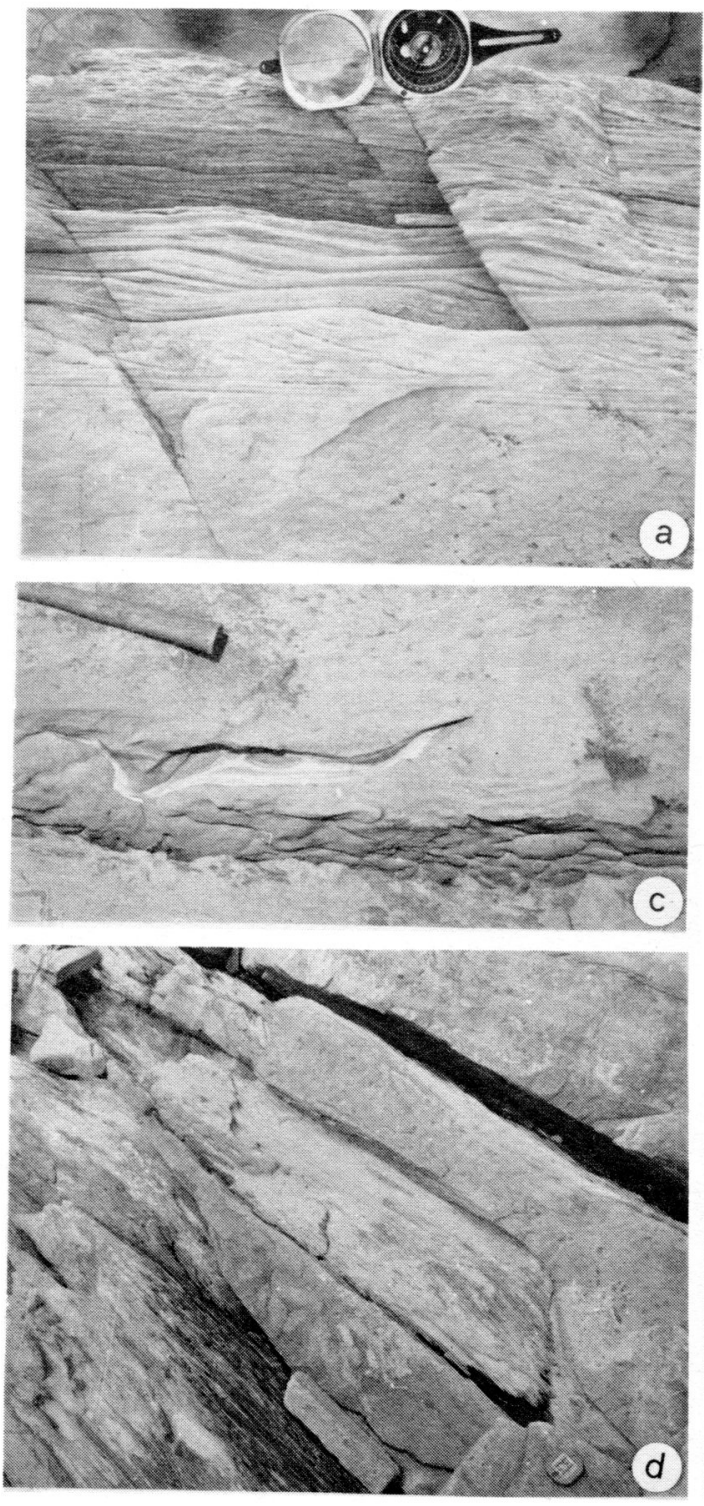
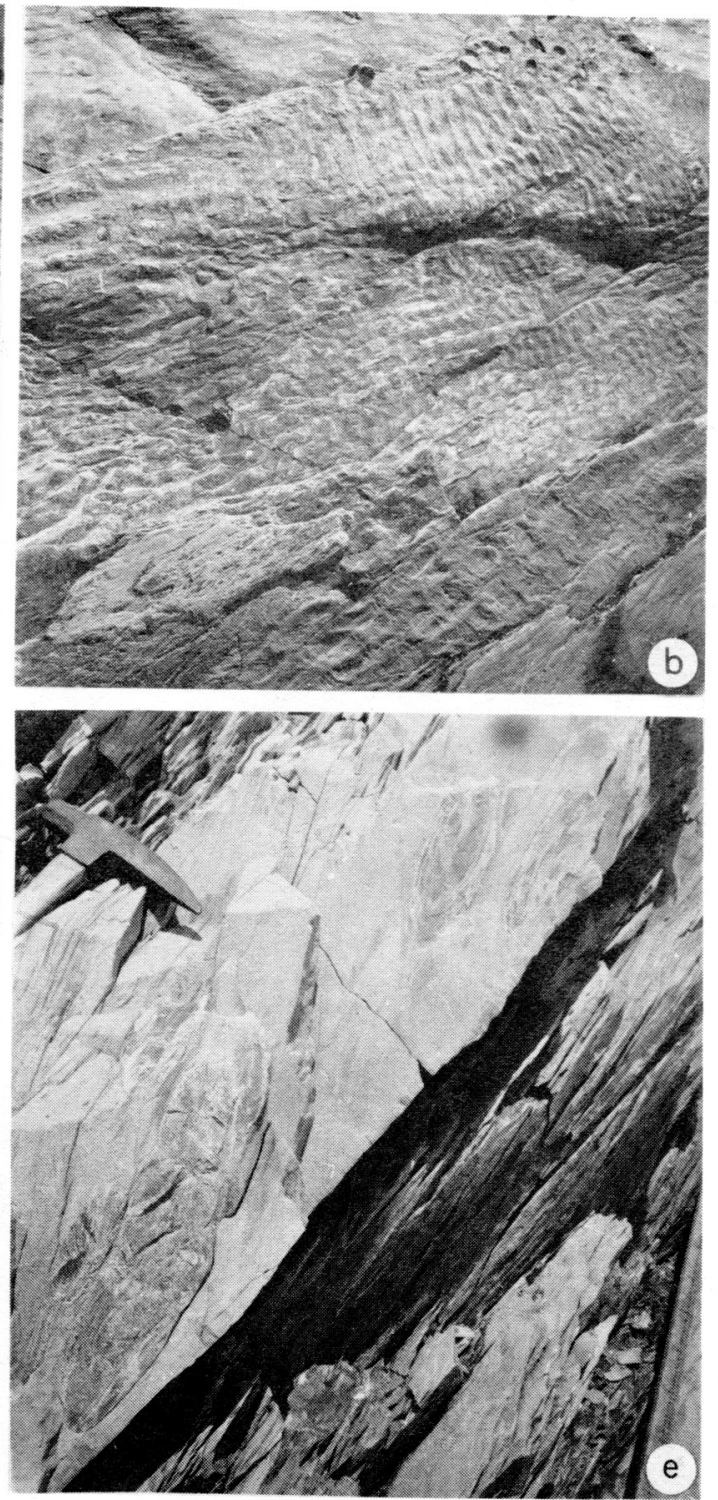

FIG. 8. Sedimentary structures in the Goldenville Formation (Stop 8), a. Structureless sandstone (Bouma A division), succeeded upwards by a zone of parallel lamination (Bouma B division), ripple-drift cross-lamination (Bouma C), and parallel fine lamination (Bouma D), Taylor Head. b. Transverse and crescentic ripple marks on upper bedding surface of a sandstone bed, Phoenix Island. c. Intraformational clast and dimpled load and flute structures, Taylor Head. d. Large intraformational clast, Phoénix Island. e. Balled-up intraformational clasts, Phoenix Island.

Parallel lamination. Diffuse parallel lamination is present in about half of the sandstone beds. This lamination commonly is developed in the lower part of the beds, but also may occur at various levels or throughout a bed. The diffuse lamination is distinct from the sharply-defined, parallel lamination (Bouma $B$ division, Fig. 8a) that occurs towards the top of some of the beds, as previously noted. Thin parallel laminae occur abundantly in the fine-grained beds.
Compound stratification. A majority of sandstone beds, particularly those exceeding a metre in thickness, exhibit compound (multiple) layering. Each layer is bounded above and below by surfaces of erosion or non-deposition, or by the bottom or top of the bed.

Ripple marks and ripple cross-lamination. Ripple marks that occur at the upper bedding surfaces of sandstone beds tend to be well displayed due to the preferential weathering and erosion of 

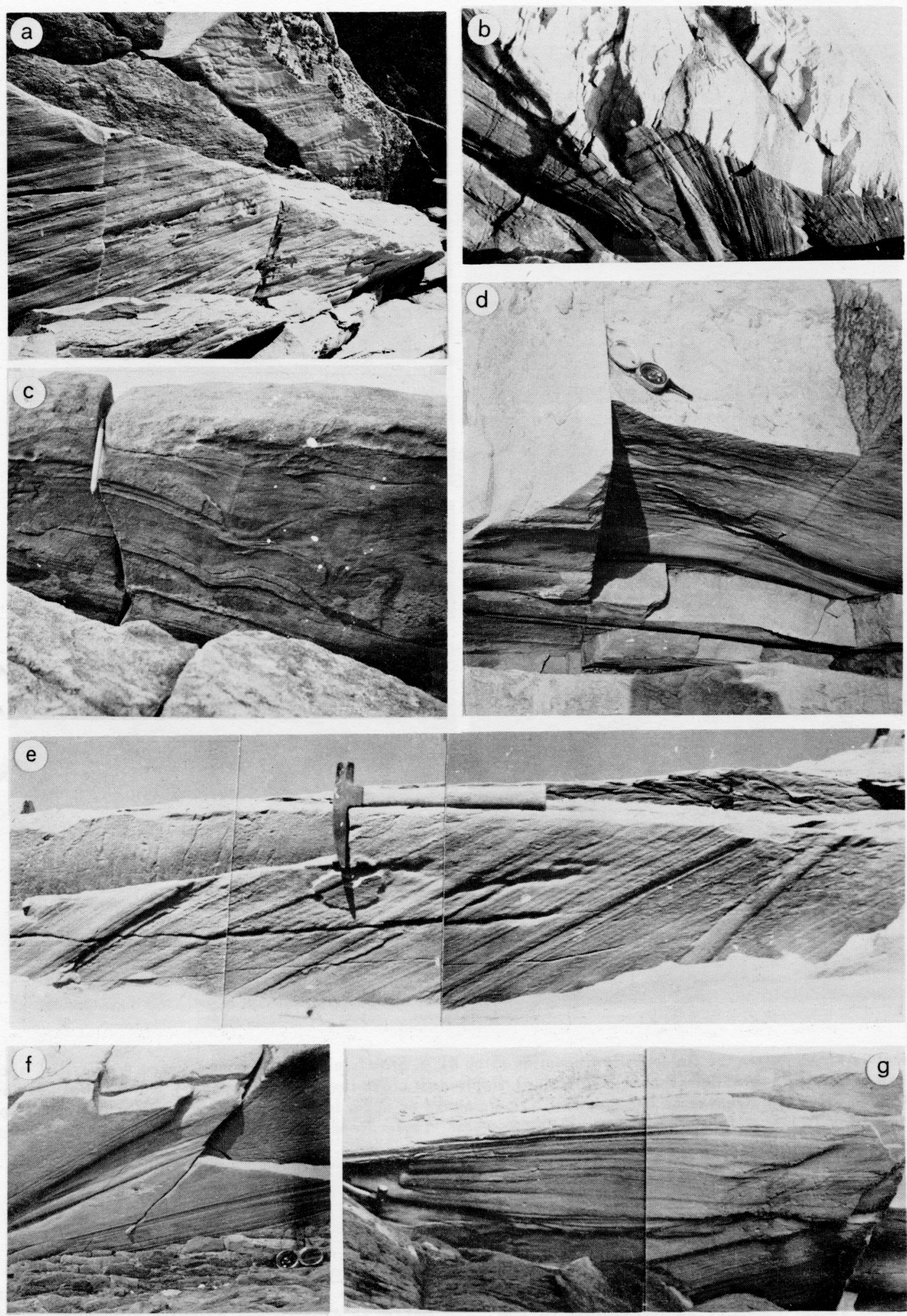

FIG. 9. Groove moulds on the under-surface of sandstone beds, Goldenville Formation (Stop 8). a. Grooves on the soles of the two beds; the lower has sharply tooled grooves, the upper has erosionally smoothed. grooves, Psyche Island. b. Prominent grooves in three directions, Taylor Head. c. Grooves deflected by the tool that formed the faint grooves transverse to the deflected grooves, Taylor.Head. d. Grooves on two intrabed surfaces, in places superimposed on scour depressions, Taylor Head. e. Grooves in two directions; an intrabed surface is visible to the left of the hammer, and the sole of an overlying bed with shallow flutes to the right of the hammer, Taylor Head. f. Grooves with streaked-out flute moulds and shallow channel moulds, and intrabed parting surface with oblique tensional (?) markings, Phoenix Island. g. Prominent grooves, spiralled on the right and terminated in prod moulds on the left near the hammer, Taylor Head. 


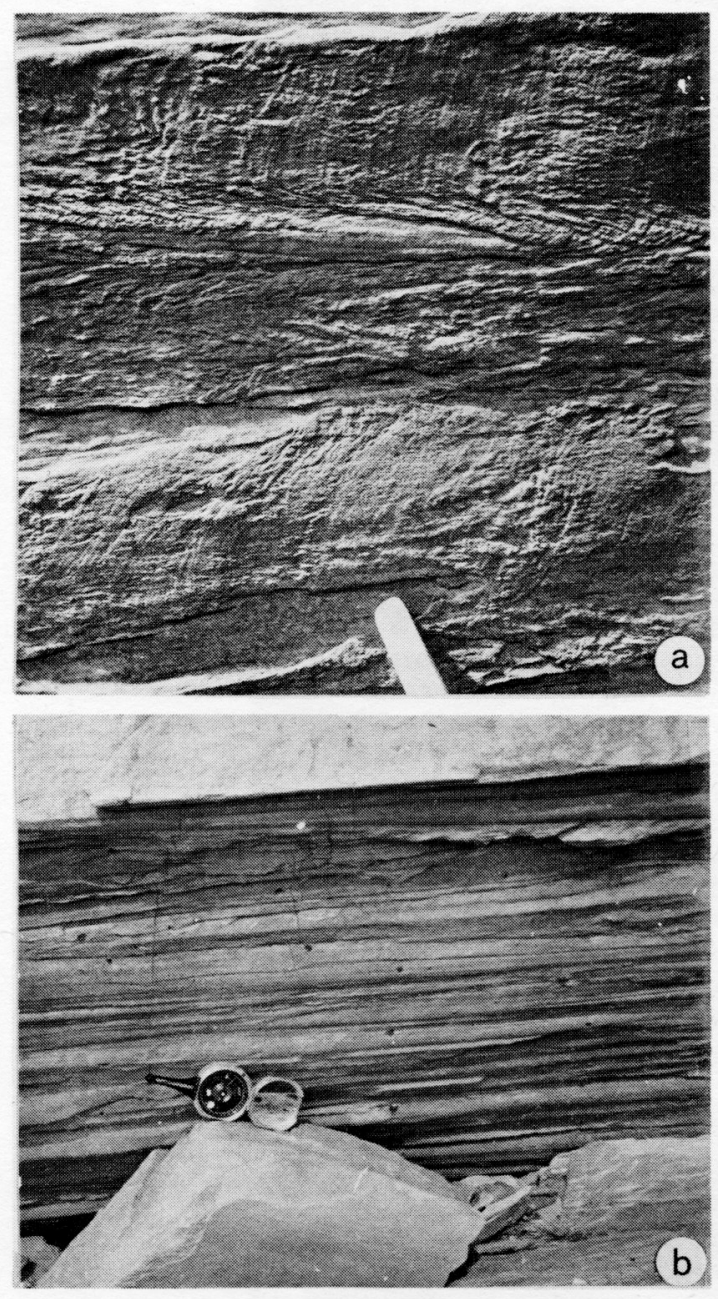

FIG. 10. Tool moulds on under-surface of sandstone beds, Goldenville Formation (Stop 8). a. Brush moulds deflected by later grooves, Psyche Island. Stick at bottom of picture is $3 \mathrm{~cm}$ wide. b. Groove moulds, both sharply defined and erosionally modified, Taylor Head. the overlying siltstone and slate (Fig. 8b). Such ripples were probably formed by the 'tails' of turbidity currents, although some may have resulted from reworking of the sediment by indigeneous bottom currents. An example of ripple-lamination with undoubted turbidite affinities is shown in Fig. 8a, although the vertical sequence of structures that identify this bed, or at least the upper part of it, as a turbidite are uncharacteristically well developed. Ripple-lamination also occurs in numerous thin beds of very fine-grained sandstone and siltstone. Convolutions associated with the Bouma $C$ division of ripple-lamination are conspicuous by their absence - none were observed in the area, unless some varieties of slump structures (see below) can be equated with convolutions.

Intraformational clasts. These 'rip-ups' occur in about 50 percent of the sandstone beds. They are generally elongate fragments several centimetres or tens of centimetres in length (Figs. 8c, e), but many exceed a metre in length ( $F$ ig. 8d).

Groove moulds. Grooves and related tool markings are extraordinarily abundant; they occur on the under-surfaces of 85 percent of the sandstone beds. Examples are illustrated in Figs. 9 and 10). Intrabed surfaces with groove markings (Hubert et al. 1966) are quite common (Fig. 9d). The interal grooves typically occur in association with scour depressions (internal flutes and small channels) and insipient, tensional separations oblique to the lineation of the grooves and associated current structures (see intrabed parting surfaces, Fig. 9f, g).

Flute moulds and associated structures. Flute moulds occur on the soles of approximately 15 percent of the sandstone beds. The most common type are closely-spaced, shallow flutes associated with longitudinal furrows ( $\mathrm{Fig}$. 1la). In some cases the flutes are little more than cuspate cross-bars between longitudinal ridges (Fig. Ilb)。 Larger and deeper flutes tend to be load-deformed (Fig. llc, d) and are commonly associated with grooves. Internal flutes (scour-and-fill structures at intrabed parting surfaces, Fig. lle) occur in approximately equal abundance to sole flutes. Internal flutes are commonly delineated on joint or fracture surfaces by trough cross-laminae (Fig. llf). The internal flutes range from about $10 \mathrm{~cm}$ to more than $100 \mathrm{~cm}$ in length, and generally are notably larger than typical flutes on bed soles.

Load structures. These vary from slight bulges several $\mathrm{cm}$ across to large, irregular proturberances several metres in length and depth, and occur at the base of many beds. Flame structures (Walton 1956) generally occur in intimate association with the load structures.

Slide markings. These occur at or near the top of many sandstone beds ( $F$ igs. $12 \mathrm{a}, \mathrm{b}$ ), and are present on a number of parting and bottom surfaces as well. These markings are generally associated with slump-deformed bedding, particularly of the type shown in Fig. 12c. 


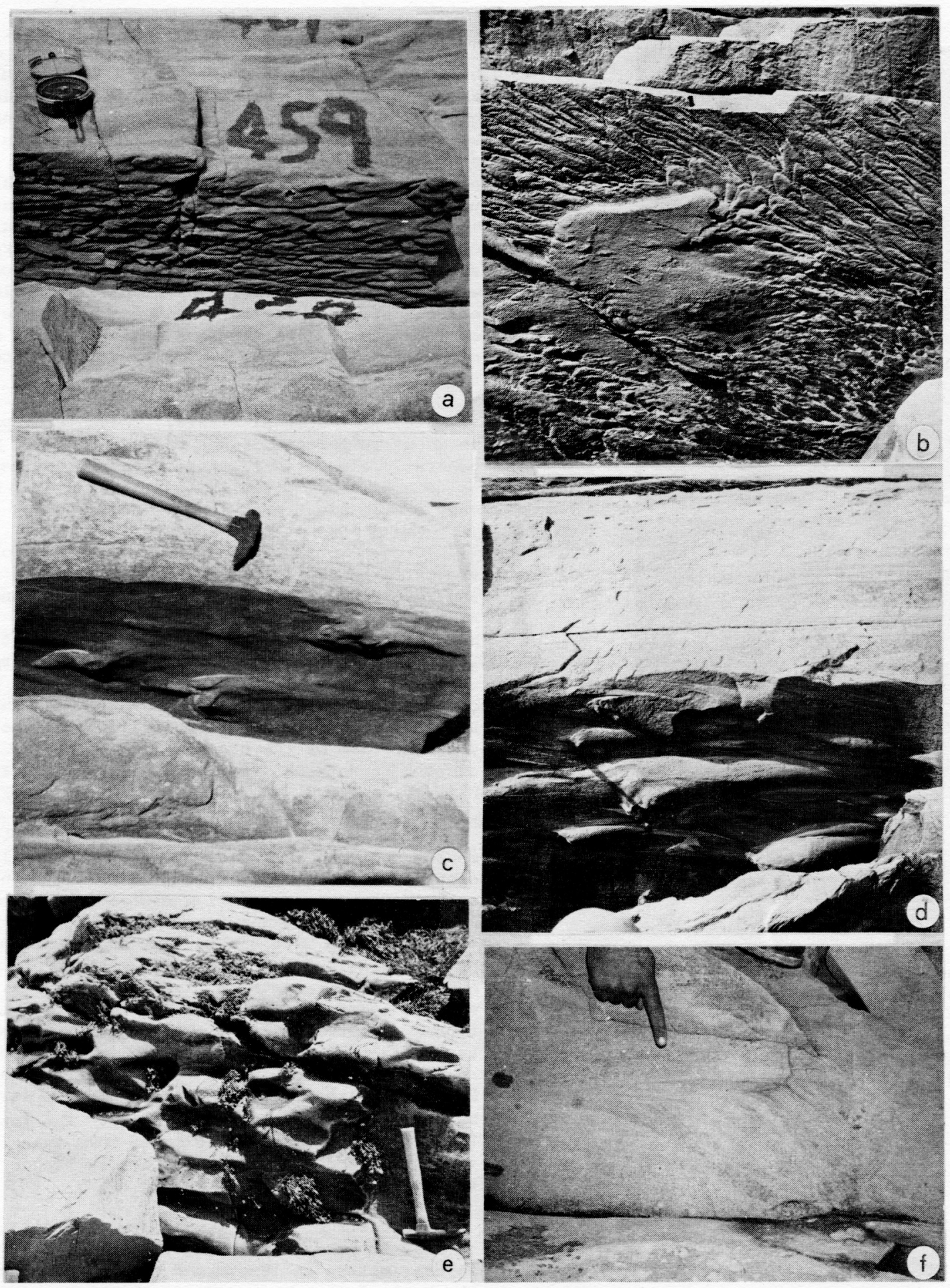

FIG. 11. Scour depressions on under-surface and within sandstone beds, Goldenville Formation (Stop 8). a. Closely-spaced, shallow flute moulds, longitudinal ridges, and dimpled structures, Taylor Head. b. Longitudinal ridges with subsidiary, shallow flutes, Psyche Island. c. Elongate and load-deformed flute moulds, Taylor Head. d. Load-deformed flute moulds superimposed on groove moulds, Psyche Island. Shadow across 'he bottom of the bed and at the upper left cast by a stick $3 \mathrm{~cm}$ wide. e. Flute marks on an intrabed parting Taylor Head. f. Cross-lamination associated with an internal scour depression, Taylor Head. 


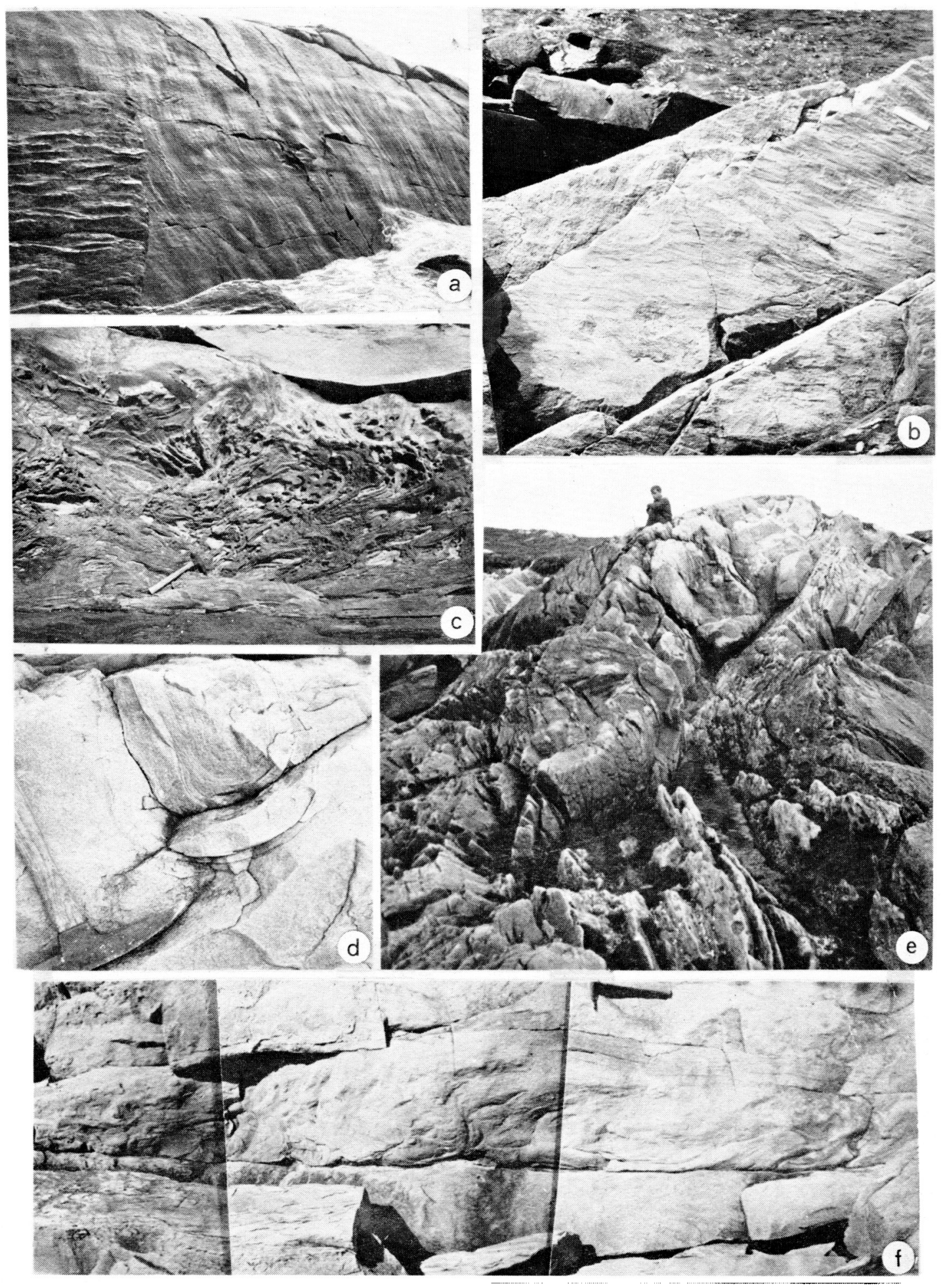

FIG. 12. Slide marks and slump-deformed beds, Goldenville Formation (Stop 8). a. Slide marks on upper bedding surface of sandstone bed, Taylor Head. Tectonically oversteepened ripple marks occur on an overlying bed. b. Slide marks on an intrabed parting surface, Phoenix Island. c. Slump-deformed bed, consisting of deformed laminae, detachment bodies and injection dykes of sandstone interspersed in argillaceous material, Phoenix Island. d. Primary fold in laminated sandstone, Taylor Head. e. Slump-deformed beds with primary folds throughout, Taylor Head. f. Slump-deformed, lower portion of bed, with relatively undeformed bedding above, and separated from undeformed sandstone bed below by a thin layer of argillaceous material, Taylor Head. 

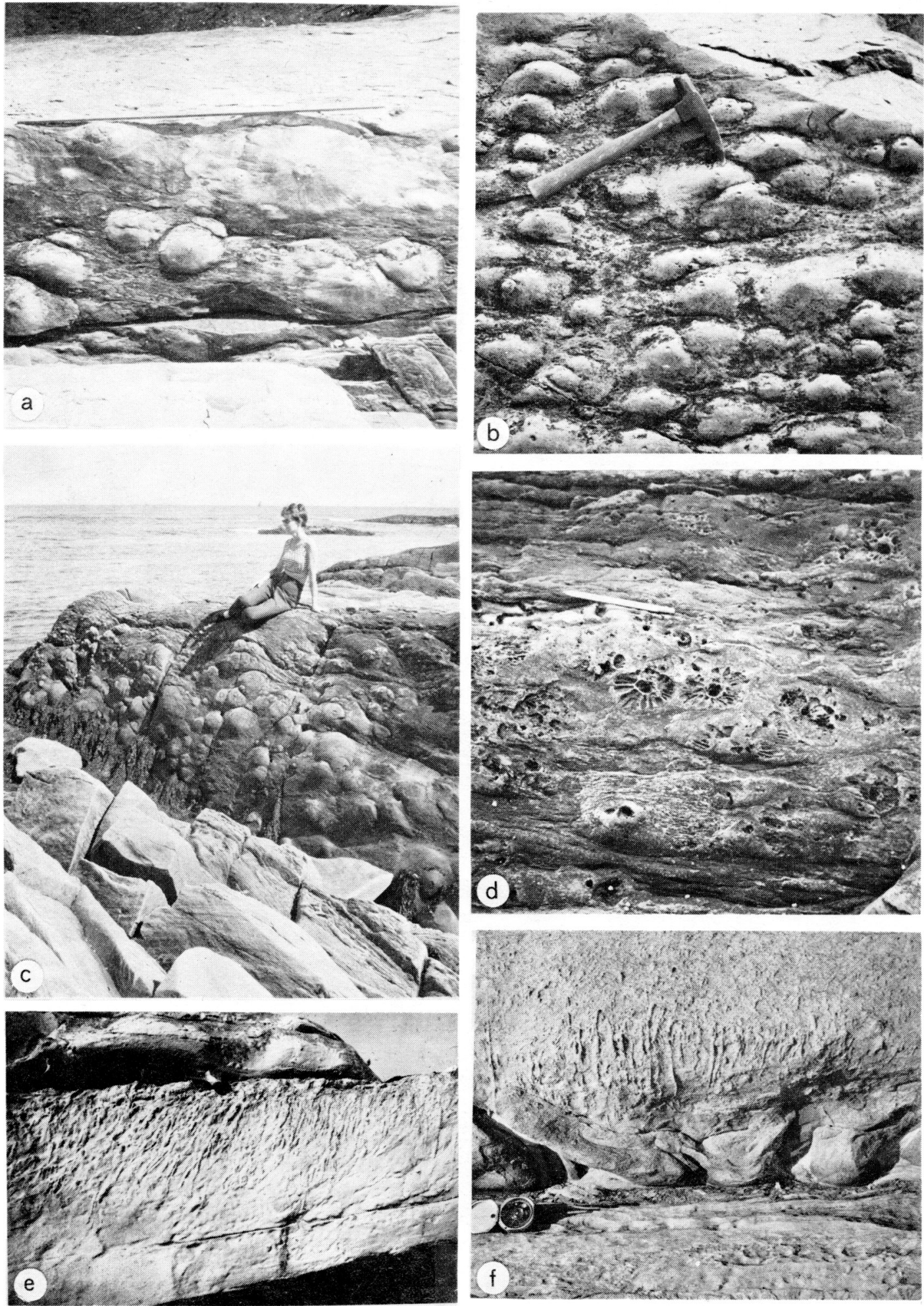

FIG. 13. Dewatering structures, Goldenville Formation (Stop 8). a. Large sand volcanoes, Phoenix Island. The length of the stick is exactly $2 \mathrm{~m}$. b,c. Sand volcanoes, Taylor Head. d. Erosionally beheaded sand volcanoes, showing plate-like structures that in each case radiate outward from a central aperture. e,f. Pillar structures. Note undeformed pillars above load-balls in $f$. 

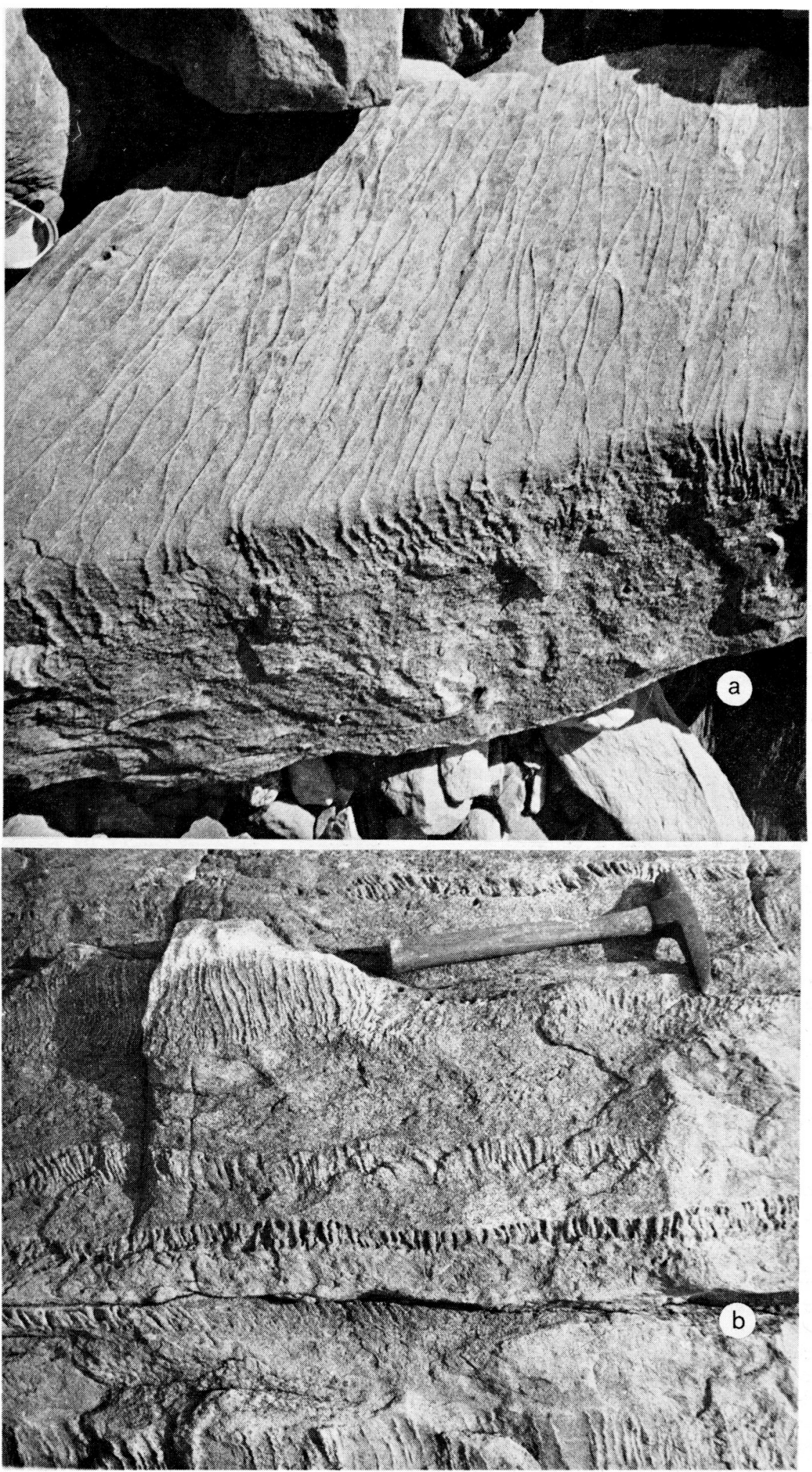

FIG. 14. Sheet structures, Goldenville Formation (Stop 8). a. Sheet structures displayed in rock slab derived from sandstone bed, Phoenix Island. The structures occur as undulous, anastomosing and slightly raised ridges on the weathered (upper) parting surface, and as sinuous sub-parallel ridges with branching terminations on the joint surface. b. Sheet structures in sandstone occurring in layers separated by structureless sandstone. 
Primary folds occur in about 60 percent of the beds. These structures are mainly the result of slump-deformation, and may be grouped into two main categories. The first and most abundant type is characterized by highly contorted and diffuse laminae and injection dykes of arenaceous material interspersed in argillaceous and silty sediment (Fig. 12C). Such units generally have a graded aspect, in that the proportion of argillaceous material increases upwards and the contorted, arenaceous laminae and injection dykes become more widely spaced and diffuse in the same direction. The slump-deformed bed shown in Fig. 12c has a relatively thin, undeformed, basal sandstone portion, but in most cases the undeformed sandstone portion is much thicker than this. This type of deformation may have been formed in lieu of Bouma $C$ convolutions during and/or following the deposition of highly water-laden sediments. The second main type comprises primary folds and deformation features resulting from plastic flow in sandstone beds, either in single beds or in groups of beds (Figs. 12a, e, f). Many of these slumped units occur above thin layers of argillaceous material, which probably acted as a lubricant that facilitated slippage. Some beds have slump-contortions in their lower portions, with relatively undeformed bedding above (Fig. 12f). In such cases, the slumping apparently took place before the upper part of the bed was deposited.

Sand volcanoes (Figs. $13 \mathrm{a}, \mathrm{b}, \mathrm{c}$, d) occur on the upper bedding surfaces of approximately 30 percent of the sandstone beds. They have an average diameter of about $10 \mathrm{~cm}$ and a maximum observed diameter of $60 \mathrm{~cm}$. Each sand mound has a central depression which is the surface expression of a vent that extends, generally many centimetres, into the sandstone below. The vents are subcylindrical cores or pillars consisting of relatively matrixfree sandstone, commonly impregnated with calcite cement. External, radial grooves occur on many of the sand mounds (Fig. 13a), a product of discrete sand flows down the sides of the developing mounds, analogous to lava flows down the sides of volcanic cones. Internally, some sand volcanoes have radial plate-like structures that extend outward from the central aperture (Fig. 13d). The radial plates are absent in other examples. They may have developed initially as fractures resulting from the pressure of upwelling water during the dewatering process.

Pillar structures (Figs, 13e, f) occur in about 35 percent of the sandstone beds. They are commonly associated with sand volcanoes, but are also prolific in beds without sand volcanoes. The pillars are subcylindrical tubes that tend to be straightsided in their upper portions, but become branched and diffuse downwards. The pillars are about 0.8 $\mathrm{cm}$ in diameter, on average, and generally do not exceed $2 \mathrm{~cm}$ in diameter, although very large pillars (maximum observed diameter $6 \mathrm{~cm}$ ) are rarely present. Most of the pillars probably formed as a result of liquefaction processes closely allied to those which produced the sand volcances. Some may have formed by 'settling convection' in a dense suspension of sediment during the final phase of deposition (Kuenan 1968). Some are post-depositional structures. The pillars illustrated in Fig. 13f, for example, clearly formed subsequent to the development of load-balls at the base of the bed. A proportion of the pillars may be biogenic structures, particularly those that are unbranched over their exposed length (up to $75 \mathrm{~cm}$ ) (Hallam and Swett 1966). Such pillars have the general appearance of Scolithus tubes. The sandstone in the pillars generally contains less matrix than the enclosing sandstone. Because of this, welding by pressure solution of the constituent quartz and other framework grains is more advanced than in the enclosing sandstone, with the result that the pillars stand out in outcrop as slightly raised ridges. The same reasoning applies to the radial plate-like structures in sand volcanoes referred to above and the sheet structures discussed below.

Sheet structures. Vertical and subvertical sheet structures occur in about 15 percent of the sandstone beds. On weathered parting surfaces parallel to bedding, the sheets occur as swarms of slightly raised ridges that individually trace a wavy path over the bedding surface (Fig. 14a). In section, the sheets are sinuous, subparallel features that generally fork into two or more branches in their lower extremities. The sandstone within the sheets contains less matrix than that without, and calcite cement is commonly present. In slump-deformed beds, the sheets are deformed along with the bedding. Laird (1970) observed identical structures in a Silurian turbidite sequence in Ireland. He found that the sheets tend to occur parallel to the sedimentary grain fabric (i.e. the sheets occur parallel to paleocurrent directions), and, by analogy with 'settling convection' structures produced experimentally by Kuenen (1968), he interpreted the sheets as features formed during the last stage of deposition of the sediment. In the Goldenville Formation, the sheet structures commonly occur as stratiform layers within a sandstone bed (Fig. 14b). This characteristic may have resulted from pulsations of the depositional current during one episode of sedimentation, or it may reflect a succession of separate sedimentation episodes.

\section{References}

BENSON, D.G., 1967, Geology of Hopewell map-area. Geol. Surv. Can., Mem. 343, 58 p.

CAMPBEIL, F.H.A., 1966, Paleocurrents and sedimentation of part of the Meguma Group (Lower Paleozoic) of Nova Scotia, Canada. unpubl. M.Sc. thesis, Dalhousie Univ。, 91 p.

CORMIER, R.F. and SMITH, T.E., 1973, Radiometric ages of granitic rocks, southwestern Nova Scotia. Can. J. Earth Sci., v. 10, p。 1201-1210.

CROSBY, D.G., 1962, Wolfville map-area, Nova Scotia (21 H/1). Geol. Surv. Can.', Mem. 325, 67 p.

DEWEY, J.F. and KIDD, W.S.F., 1974, Continental collisions in the Appalachian - Caledonian orogenic belt: variations related to complete and incomplete suturing. Geology, v. 2, p. 543-546. 
DOUGLAS, G.V., MILNER, R.L. and MACLIAN, J., 1938, The deposition of the Halifax series. N.S. Dept. Public Works and Mines, Ann. Rept., pt. 2, p. 34-45.

FAIRBURN, H.W., HURLEY, P.M., PINSON, W.H. and CORMIER, R.F., 1960, Age of granitic rocks of Nova Scotia: Geol. Soc. Am., Bull., v. 71, p. 399-413.

FAIRBURN, H.W., HURLEY, P.M. and PINSON, W.H., 1964, Preliminary age study and initial ${ }^{87} \mathrm{Sr} /{ }^{86} \mathrm{Sr}$ of Nova Scotia granitic rocks by the Rb/Sr whole rock method. Geol. Soc. Am. Bull., v. 75, p. 253-258.

FARIBAULT, E.R., 1914, Greenfield and Liverpool Town map-areas, Nova Scotia. Geol. Surv. Can., Surm. Rept. 1912, p. 334-340.

FYSON, W.K., 1966, Structures in the Lower Paleozoic Meguma Group, Nova Scotia. Geol. Soc. Am., Bull., v. 77, p. 931-944.

HALLAM, A. and SWETT, K., 1966, Trace fossils from the Lower Cambrian Pipe Rock of the northwest Highlands. Scott. Jour. Geology, v. 2, p. 101-106.

HARLAND, W.B. and GAYER, R。A., 1972, The Arctic Caldeonides and earlier oceans. Geol. Mag., v. 109, p. 289-314.

HARRIS, I.M., 1971, Geology of the Goldenville Formation, Taylor Head, Nova Scotia. unpubl. Ph.D. thesis, Univ。 Edinburgh, 224 p.

, 1975, Sedimentological study of the Goldenville Formation, Nova Scotia. Geol. Surv. Canada, Paper 75-1(A), p. 171-174.

HEEZEN, B.C., HOLLISTER, D.C., and RUDDIMAN, W.F., 1966, Shaping of the continental rise by deep geostrophic contour currents. Science, v. 152 , p. 502-508.

HORN, D.R., EWING, M., HORN, B.M. and DELACH, M.N., 1971, Turbidites of the Hatteras and Sohm Abyssal Plains, western North Atlantic. Marine Geol., v. 11, p. 287-323.

HUBERT, J॰F., 1966, Sedimentary history of upper Ordovician geosynclinal rocks, Girvan, scotland. Jour. Sed. Pet., v. 36, p. 677-699。

, 1968, Currents and slopes in flysch basins: a discussion. Jour. Sed, Pet., v. 38, p. 1390-1393.

HUBERT, J.F., SCOTT, K.M. and WALTON, E.K., 1966, Composite nature of Silurian flysch sandstones shown by groove moulds on intra-bed surfaces; Peebleshire, Scotland. Jour. Sed. Pet., v. 36, p. 237-241.

HURLEY, P.M., BOUDDA, A。, KANES, W.H. and NAIRN, A. E.M., 1974, A plate tectonics origin for Late Precambrian - Paleozoic orogenic belt in Morocco. Geology, v. 2, p. 343-344.
JANSA, L。F。 and WADE, J.A. 1975, Geology of the Continental margin off Nova Scotia and Newfoundland; in Offshore Geology of Eastern Canada, Geol. Surv。Canada, Paper 74-30, v. 2, p. 51-105.

KING, L.Ho and MACLEAN, B., 1974, Geology, Scoti.an Shelf and adjacent areas. Map with crosssections, publ. Canadian Hydrographic Service, Dept. Environment, Ottawa.

KLEIN, G.D。, 1966, Dispersal and petrology of sandstones of the Stanley-Jackfork boundary, Ouachita fold belt, Arkansas and Oklahoma. Bull. Amer. Assoc. Pet. Geol., v. 50, p. 308326.

KUENEN, Ph.H., 1968, Settling convection and grainsize analysis. Jour. Sed. Pet., v. $38, \mathrm{p}$. 818-831.

LAIRD, M.G., 1970, Vertical sheet structures - a new indicator of sedimentary fabric。 Jour, sed. Pet., vo 70, p. 428-434。

LEECH, G.B., LOWDON, J.A., STOCKWELL, C.H. and WANLESS, R.K., 1963, Age determinations and geological studies, Geol. Surv. Can., Paper $63-17,140 \mathrm{p}$.

LOWDON, J॰A., STOCKWELL, C.H०, TIPPER, H.W० and WANLESS, R.K., 1963, Age determinations and geological studies, Geol. Surv, Can。, Paper 62-17, $140 \mathrm{p}$.

MALCOLM, W., 1929, Gold fields of Nova Scotia, Geol. Surv. Can., Mem. 156, 253 p。

MCKERROW, W.A. and ZIEGLER, A.M., 1973, Paleozoic oceans. Nature Physical Sci., vo 240, p. 9294.

MIDDLETON, G。V。 and HAMPTON, M.A., 1973, sediment gravity flows: mechanisms of flow and deposition; in Turbidites and deep-water sedimentation. Soc. Econ. Paleontologists and Mineralogists, Pacific Section, Los Angeles, Short Course Notes, p。1-38.

MUTTI, EMILIANO, 1974, Examples of ancient deepsea fan deposits from circum-Mediterranean geosynclines; in Dott, R.H. and Shaver, R。H. (eds.), Modern and Ancient Geosynclinal Sedimentation. Soc。 Econ. Paleontologists and Mineralogists, Spec. Pub. 19, p. 92-105.

NELSON, CoH. and KULM, L.D., 1973, Submarine fans and deep-sea channels; in Turbidites and deepwater sedimentation. SOC. Econ. Paleontolgists and Mineralogists, Pacific Sec., Los Angeles, Short Course Notes, p. 39-70.

NELSON, C.Ho and NILSEN, T.H॰, 1974, Depositional trends of modern and ancient deep-sea fans; in Dott, R。H. and Shaver, R.H. (eds.), Modern and Ancient Geosynclinal Sedimentation. Soc. Econ. Paleontologists and Mineralogists, Spec。Publ. 19, p. 69-91. 
PHINNEY, W.C., 1961, Possible turbidity-current deposit in Nova Scotia. Geol. Soc。Am。 Bull., v. 72, p. 1453-1454。

POOLE, W.H., 1967, Tectonic evolution of Appalachian region of Canada. Geol. Ass. Can., Spec. Paper 5, p. $9-51$.

1971, Graptolites, copper and potassiumargon in Goldenville Formation, Nova Scotia; in Report of Activities, Part A, April to October 1970. Geol. Surv。Can., Paper 71-1A, p. 9-1l.

POOLE, W.H. KELLEY, D.G. and NEALE, E.R.W., 1964, Age and correlation problems in the Appalachian region of Canada. Roy. Soc. Can., Spec. Publ. 8, p. 61-84.

POOLE, W०H。, SANFORD, $\mathrm{B}_{0} \mathrm{~V}_{0}$, WILLIAMS, $\mathrm{H}_{\circ}$ and KELLEY, D.G., 1970, Geology of southeastern Canada; in Geology and Economic Minerals of Canada, Geol. Surv. Can., Econ. Geol. Rept. 1, 5 th ed., p. 228-304.

REYNOLDS, P.H。, KUBLICK, E.E. and MUECKE, G.K。, 1973, Potassium-argon dating of slates from the Meguma Group, Nova Scotia. Can. J. Earth Sci., v. 10, p. 1059-1067.

SCHENK, P.E., 1970, Regional variation of the flyschlike Meguma Group (Lower Paleozoic) of Nova Scotia compared to Recent sedimentation off the Scotian Shelf. Geol. Assoc. Can. i Spec。 Paper 7, po 127-153.

- 1971, Southeastern Atlantic Canada, northwestern Africa, and continental drift. Can. J. Earth Sci., v. 8, p. 1218-1251.

, 1972a, Eastern Canada as successive remnants of northwestern Africa. 24th Internat. Geol. Congress (Montreal), section 6, p. 14-23.

, 1972b, Possible Late Ordovician glaciation of Nova Scotia. Can. J. Earth Sci., v. 9, p. 95-107.

1973, Nova Scotia, Morocco and continental drift; in Earth Science Symposium on offshore Eastern Canada. Geol. Survo Can., Paper 71-23, p. 219-222.

, 1975, The Paleozoic evolution of African Nova Scotia, Canada - abyssal and polar to continental and equatorial. Int. Assoc. Sed., Nice, in press.

SCOTT, K.M॰, 1966, Sedimentology and dispersal pattern of a Cretaceous flysch sequence, Patagonian Andes, Southern Chile. Bull. Amer. Assoc. Petrol. Geol., v. 50, p. 72-107.

SMITH, T.E., 1974, The geochemistry of the granitic rocks of Halifax County, Nova Scotia. Can. J. Earth Sci., v. 11, p. 650-657.

SMITHERINGALE, W.G., 1973, Geology of parts of Digby, Bridgetown, and Gaspereau Lake map- areas, Nova Scotia. Geol. Surv. Can., Mem. $375,78 \mathrm{p}$.

STEVENSON, I。M., 1959, Shubenacadie and Kennetcook nap-areas, Colchester, Hants and Halifax Counties, Nova Scotia. Geol。Surv. Can., Mem. $302,88 \mathrm{p}$.

TAYLOR, F.C., 1967, Reconnaissance geology of Shelburne map-area, Queens, Shelburne, and Yarmouth Counties, Nova Scotia, Geol。 Surv. Can., Mem. 349, 83 p.

- 1969, Geology of the Annapolis-St. Mary's Bay map-area, Nova Scotia. Geol。 Surv. Can。, Mem. 358, 63 p.

TAYLOR, F。C。 and SCHILLER, E。A., 1966, Metamorphism of the Meguma Group of Nova Scotia. Can. J。 Earth Sci。, v. 3, p. 959-974。

WALKER, R.G., 1967, Turbidite sedimentary structures and their relationship to proximal and distal depositional environments. Jo Sed. Pet., v. 37, p. 25-43.

, 1970, Review of the geometry and facies organization of turbidites and turbidite-bearing basins; in Lajoie, J. (ed.), Flysch Sedimentology in North Fmerica: Geol。Assoc. Canada, Special Paper, 7, po 219-25l.

, 1973, Mopping up the turbidite mess: in Ginsburg, R.No (ed.), Evolving Concepts in Sedimentology. John Hopkins Univ. Press, Baltimore, p. 1-37.

WALKER, RoG。 and MUTTI, E., 1973, Turbidite facies and facies associations; in Turbidites and deep-water sedimentation. Soc. Econ. Paleontologists Mineralogists, Pacific Sec。, Los Angeles, Short Course Notes, p. 119-157.

WALTON, E.K., 1956, Limitations of graded bedding and alternative criteria of upward sequence in the rocks of the Southern Uplands. Trans. Edinburgh Geol. Soc., v. 16, po 262-271.

WANLESS, R.K. STEVENS, $R_{0} D_{0}$, LACHANCE, G。R. and DELABIO, R。N., 1972, Age determinations and geological studies, K-Ar Isotopic Ages, Report 10. Geol. Surv。Can., Paper 71-2, 96 p.

WOODMAN, JoEo, 1904, Nomenclature of the goldbearing metamorphic series of Nova Scotia. AmeroGeol。, vo 33, p. 363-370。 